\title{
In Vivo and In Vitro Genetic Models of Congenital Heart Disease
}

\author{
Uddalak Majumdar, ${ }^{1,2}$ Jun Yasuhara, ${ }^{1,2}$ and Vidu Garg ${ }^{1,2,3,4}$ \\ ${ }^{1}$ Center for Cardiovascular Research, Nationwide Children's Hospital, Columbus, Ohio 43205, USA \\ ${ }^{2}$ The Heart Center, Nationwide Children's Hospital, Columbus, Ohio 43205, USA \\ ${ }^{3}$ Department of Pediatrics, The Ohio State University, Columbus, Ohio 43205, USA \\ ${ }^{4}$ Department of Molecular Genetics, The Ohio State University, Columbus, Ohio 43205, USA \\ Correspondence: vidu.garg@nationwidechildrens.org
}

Congenital cardiovascular malformations represent the most common type of birth defect and encompass a spectrum of anomalies that range from mild to severe. The etiology of congenital heart disease (CHD) is becoming increasingly defined based on prior epidemiologic studies that supported the importance of genetic contributors and technological advances in human genome analysis. These have led to the discovery of a growing number of disease-contributing genetic abnormalities in individuals affected by CHD. The evergrowing population of adult CHD survivors, which are the result of reductions in mortality from CHD during childhood, and this newfound genetic knowledge have led to important questions regarding recurrence risks, the mechanisms by which these defects occur, the potential for novel approaches for prevention, and the prediction of long-term cardiovascular morbidity in adult CHD survivors. Here, we will review the current status of genetic models that accurately model human $\mathrm{CHD}$ as they provide an important tool to answer these questions and test novel therapeutic strategies.

$\mathrm{C}$ ongenital heart disease (CHD) affects $2 \%-$ $3 \%$ of newborn infants when including cases of isolated bicuspid aortic valve (BAV) (Pierpont et al. 2018). The survival of this most common type of birth defect is increasing with tremendous improvements in the clinical management of individuals affected by CHD. This improved survival has resulted in a growing population of adult CHD survivors who now outnumber children with CHD. Unfortunately, these adult survivors often suffer from comorbid conditions and are at risk for neurodevelopmental and cognitive deficits, cardiac arrhythmias, and ventricular dysfunction, which contribute to their early mortality (Russell et al. 2018). Epidemiologic studies investigating the etiology of $\mathrm{CHD}$ have implicated both genetic and environmental factors. With recent advancement in next-generation sequencing technologies, a genetic abnormality-defined as chromosomal aneuploidy or a pathogenic chromosomal copy number or single gene variant-is able to be

Editors: Benoit G. Bruneau and Paul R. Riley

Additional Perspectives on Heart Development and Disease available at www.cshperspectives.org

Copyright (C) 2021 Cold Spring Harbor Laboratory Press; all rights reserved; doi: 10.1101/cshperspect.a036764

Cite this article as Cold Spring Harb Perspect Biol 2021;13:a036764 
U. Majumdar et al.

detected in $\sim 1 / 3$ of CHD cases (Akhirome et al. 2017). Although the majority of CHD cases remain unexplained, the discoveries of these genetic contributors have led to the development of genetic models of CHD.

In vivo and in vitro model systems are important tools to understand disease pathogenesis and progression, as well as to investigate its underlying mechanisms. In addition, these models can serve to test preclinical therapeutic interventions. Accordingly, the best models recapitulate the anatomy and physiology of the disease being studied in humans and are also cost-effective and easy to generate and manipulate. Another aspect of a translational genetic model is that the genetic abnormality has a strong and consistent association with the disease phenotype in humans. In the fields of cardiac developmental biology and CHD, numerous animal models from Drosophila melanogaster (fruit fly), Danio rerio (zebrafish), Xenopus laevis (frog), and Gallus gallus (chick), to small (mice and rats) and large mammals (sheep, dogs, and pigs) have been used along with in vitro cell culture models.

Each of these models have their own benefits and limitations. As the focus of this review is the development of genetic models of human CHD, we have emphasized the role of murine models, which are amenable to reverse genetics, share a high degree of sequence conservation to humans, and have similar stages of cardiac morphogenesis along with adult cardiac structures and physiology. In addition, the field has amassed $>25$ years of experience studying cardiac development and disease in mouse models. The murine model is not without its limitations primarily related to the time involved to generate and characterize a new mouse, which is both time-consuming and expensive. In addition, the models of CHD in mice often result in perinatal lethality, limiting our ability to study long-term cardiovascular sequelae from the genetic abnormality. Alternatively, zebrafish, a lower species vertebrate model, is quite popular because of its low cost of housing, easily available genetic tools, the embryos' lack of dependence on a functional cardiovascular system, and their optical transparency, which allows for more de- tailed analysis of cellular mechanisms. However, the utility of a relatively primitive two-chambered heart of the zebrafish is limiting for studying more complex structural abnormalities found in human CHD (Bakkers 2011). The fruit fly has similar benefits in regard to being high throughput and lower cost, but again is limited by its primitive cardiac structure (Zhu et al. 2017b). In vitro noncardiac cellbased models have been used to study potentially pathogenic sequence variants identified in affected individuals with $\mathrm{CHD}$, but have numerous limitations in regard to the biologic relevance of these observations. More recently, patient-specific induced pluripotent stem cells (iPSCs) have begun to be investigated as a model to study human CHD (Mital 2016; Mercer and Evans 2017). Somewhat similar to the weaknesses related to zebrafish and fruit fly in regard to modeling the structural and morphogenetic aspects of $\mathrm{CHD}$, these models are the most genetically similar and may allow for the investigation of the most relevant molecular mechanisms.

In this review, we discuss the genetic models of $\mathrm{CHD}$ that are linked to well-established monogenic causes of CHD with a focus on the murine model system where these CHD subtypes can be morphologically recapitulated. We have divided these models according to subtypes of $\mathrm{CHD}$, including cardiac septation defects, heart valve malformations, and conotruncal heart defects, and discussed a subset of these models in more depth to highlight the insights that can be obtained. We also discuss the development of in vivo genetic models of more complex CHD, which are unlikely to be monogenic in etiology, and look forward to the use of other model systems in lower species and in vitro modeling using iPSCs.

\section{MURINE MODELS OF CARDIAC SEPTATION DEFECTS}

Formation of a four-chambered heart with its separate pulmonary and systemic circulations requires the proper development of atrial and ventricular septa. Defects of cardiac septation are among the most common forms of $\mathrm{CHD}$ 
A

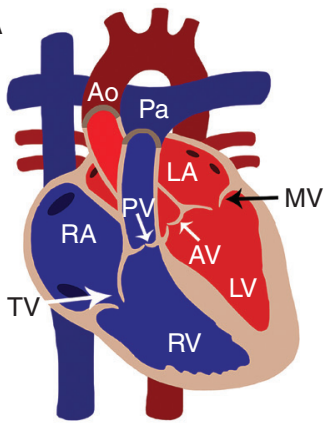

D
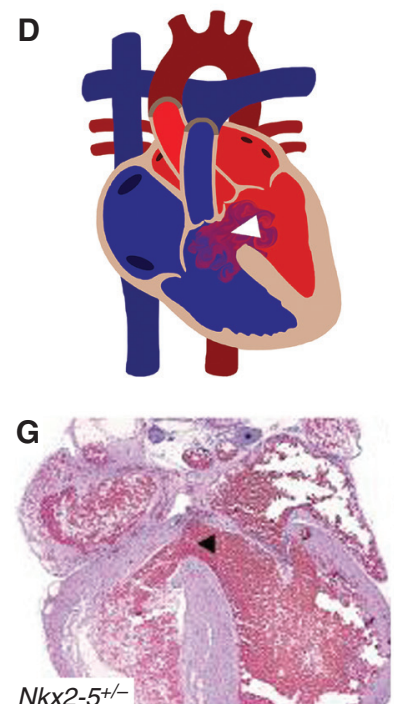

B

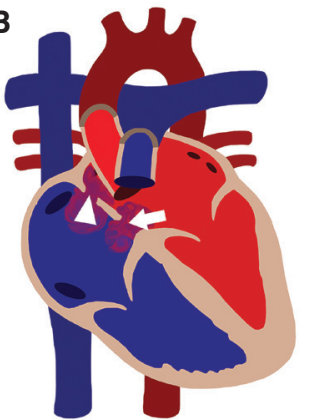

E
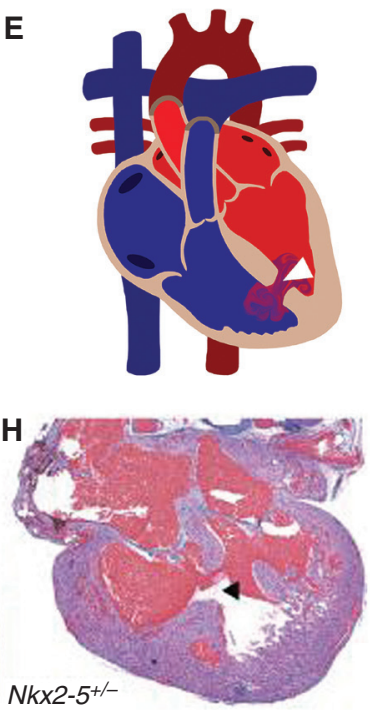

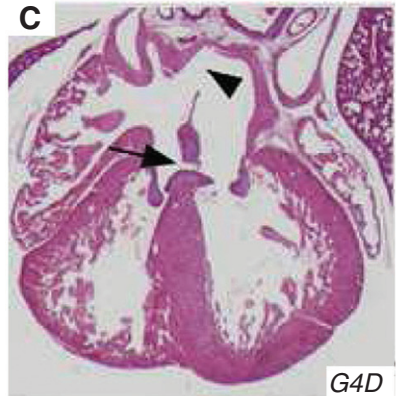

$\mathbf{F}$
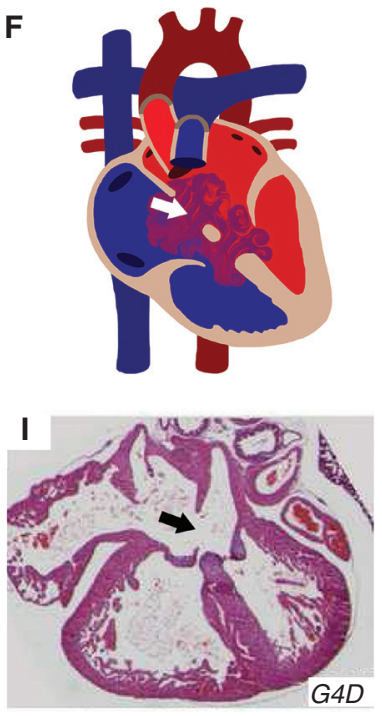

Figure 1. Murine models of cardiac septation defects: $(A)$ Illustration depicts a cross-sectional view of a normal and mature four-chambered heart. (B) Location of primum (arrowhead) and secundum (arrow) atrial septal defect (ASD) in human heart diagram, which has been recapitulated in Gata4 $4^{\operatorname{ex} 2 / W T}(G 4 D)$ mouse model (C). $(D, E)$ Schematics display similar features of perimembranous and muscular ventricular septal defects (VSDs) (arrowhead) seen in human congenital heart disease (CHD) patients, which were also detected in $N k x 2-5^{+/-}$mice $(G, H) .(F)$ The diagram represents atrioventricular septal defect (AVSD) phenotype with single valve (arrow) noted in humans, resembling the G4D murine model (I). (RA) right atrium, (RV) right ventricle, (LA) left atrium, (LV) left ventricle, (MV) mitral valve, (AV) aortic valve, (PV) pulmonary valve, (TV) tricuspid valve, (Ao) aorta, $(\mathrm{Pa})$ pulmonary artery. (Panels $C$ and $I$ are reprinted from Rajagopal et al. 2007, with permission, from Elsevier (c) 2007. Panels $G$ and $H$ are reprinted from Winston et al. 2010, with permission, from Circulation (c) 2010.)

and include atrial septal defects (ASDs), ventricular septal defects (VSDs), and atrioventricular septal defects (AVSDs) (Fig. 1). Many ASDs and VSDs are small and close spontaneously, whereas hemodynamically significant ASDs and VSDs and all AVSDs require cardiac intervention. Genetic abnormalities associated with cardiac septation defects have been well described and include pathogenic variants in single genes.
These findings have been the basis for the generation of numerous mouse models, which have provided important insights into disease mechanisms (Table 1). Studies in families with autosomal-dominant inherited CHD have linked pathogenic sequence variants in the cardiac transcription factors, TBX5, NKX2-5, and GATA4, with cardiac septation defects in humans (reviewed in Pierpont et al. 2018). 
U. Majumdar et al.
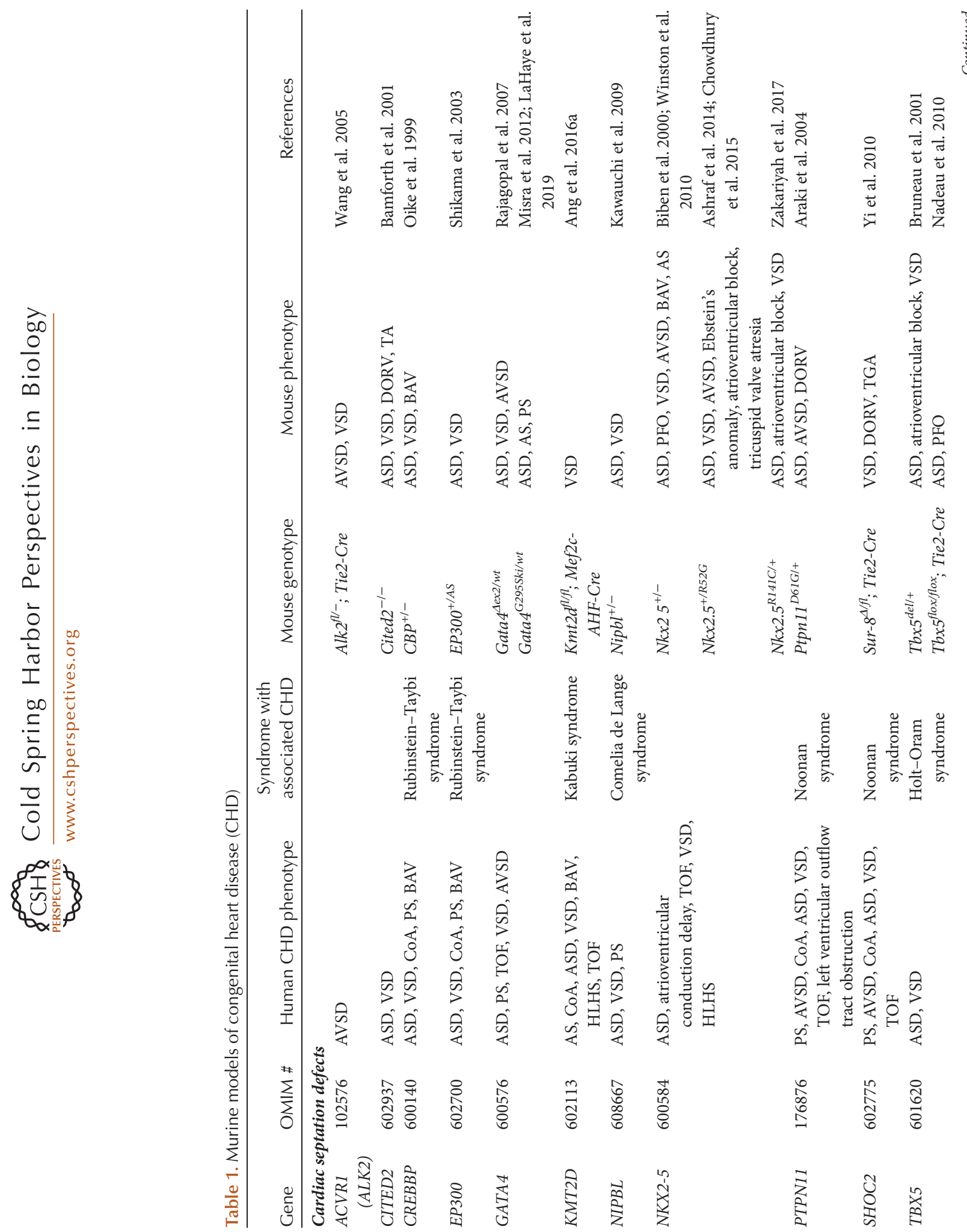
Genetic Models of Congenital Heart Disease

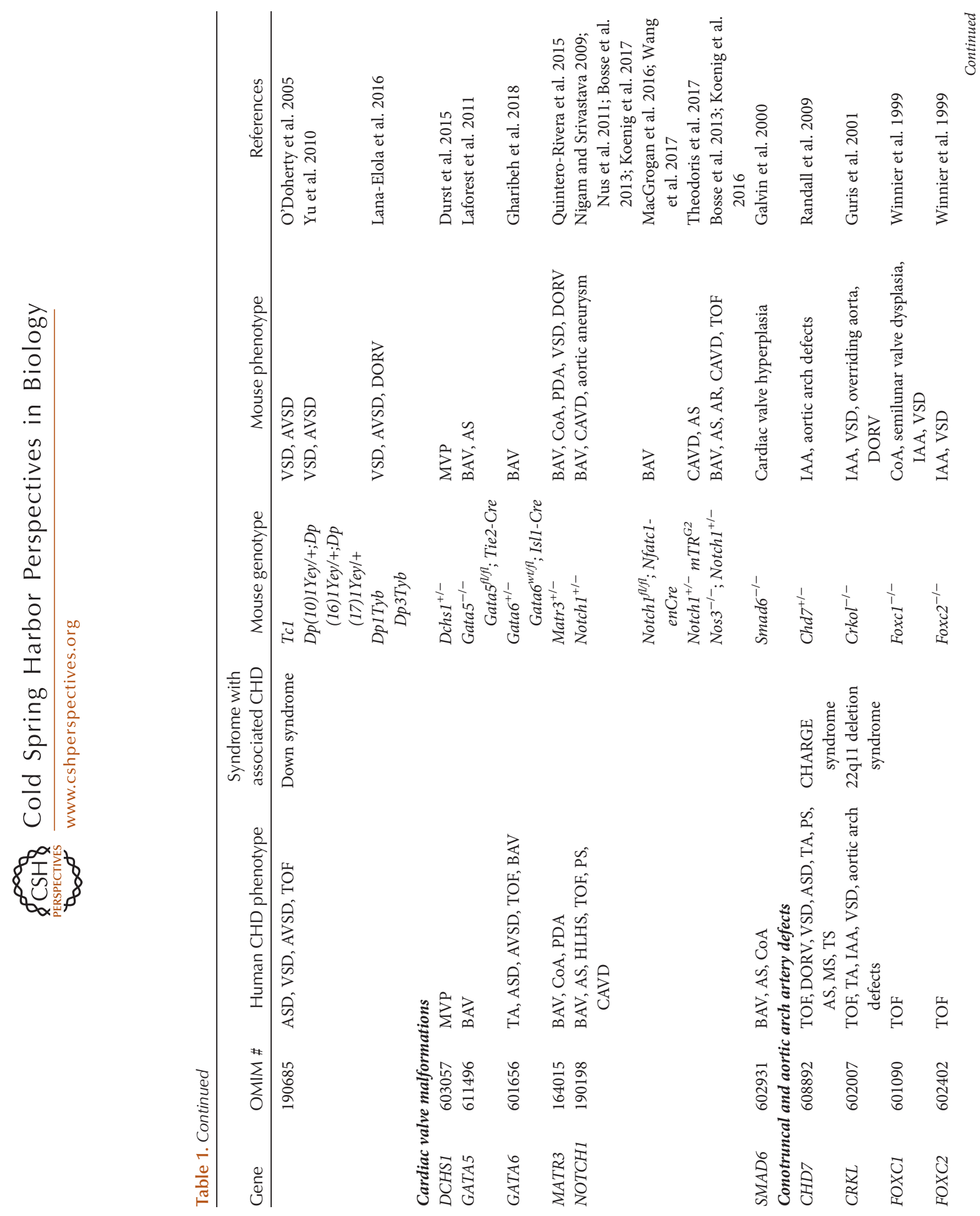


U. Majumdar et al.
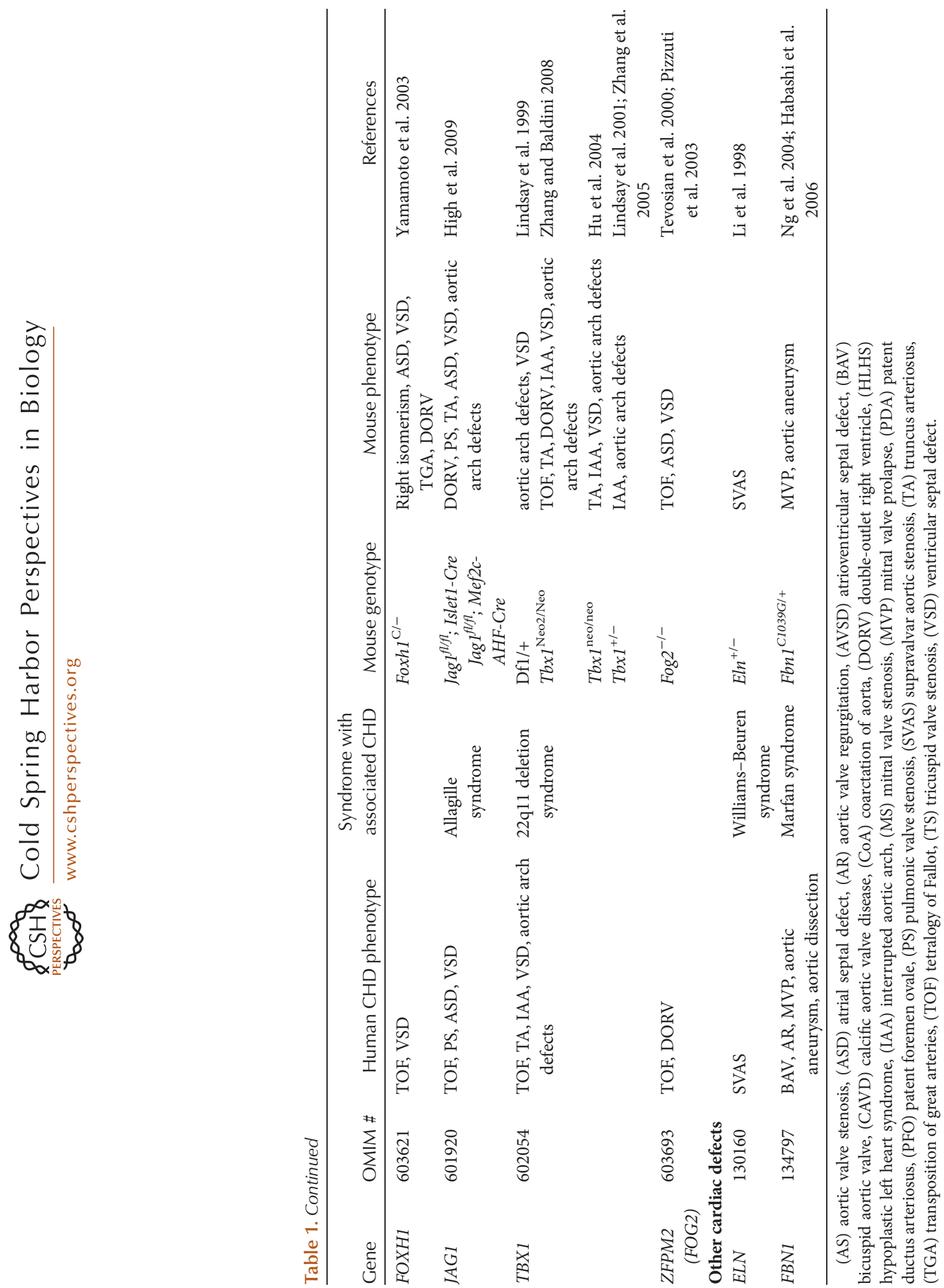


\section{TBX5}

Pathogenic sequence variants in TBX5 have been linked to Holt-Oram syndrome, which is characterized by upper limb and cardiac abnormalities (Basson et al. 1997, 1999; Li et al. 1997). Cardiac defects are found in $75 \%-85 \%$ of individuals with Holt-Oram syndrome, including ASD (to the point of common atrium), VSD, and defects in atrioventricular conduction that can progress to complete heart block (Basson et al. 1994; Newbury-Ecob et al. 1996; Bruneau et al. 1999). The majority of heterozygous pathogenic variants result in a loss-of-function allele and this has led to the successful development of a murine model for Holt-Oram syndrome, which recapitulates the majority of human disease phenotypes.

Mice heterozygous for a Tbx5 mutant allele, which deletes exon 3 that harbors the T-box domain, was generated by breeding $T b x 5^{\text {lox/+ }}$ from Black Swiss background to mice with a constitutively active Cre recombinase $\left(\mathrm{EIIa}^{\mathrm{Cre}}\right.$ from 129SvJ strain) (Bruneau et al. 2001). The resultant $T b \times 5^{\mathrm{del} /+}$ progeny were viable but displayed a $40 \%$ perinatal lethality. This perinatal lethality was increased in $T b \times 5^{d e l /+}$, when the Tbx $5^{\text {lox/+ }}$ mice were from 129 SvEv background indicating a role for genetic modifiers. The surviving adult $T b \times 5^{\text {del/ }+}$ mice from a mixed background (Black Swiss and 129SvJ) showed large ASDs along with evidence of varying degrees of atrioventricular block. Interestingly, VSDs were found only in $T b \times 5^{\mathrm{del} /+}$ embryos or neonatal mice, likely representing the reason for observed perinatal mortality. Another publication showed that complete deletion of Tbx5 from endocardial and endocardial-derived cells using Tie $2^{\text {Cre }}$ mice resulted in secundum ASD, whereas endocardial-specific heterozygous $T b \times 5$ $\left(e \mathrm{~Tb} \times 5^{+/-}\right)$deletion showed a $65 \%$ incidence of patent foramen ovale (PFO), suggesting that PFO is an attenuated manifestation of ASD (Nadeau et al. 2010).

\section{NKX2-5}

Disease-causing sequence variants in NKX2-5 were the first reported cause of nonsyndromic
Genetic Models of Congenital Heart Disease

CHD by studying four kindreds with autosomal-dominant disease (Schott et al. 1998). The predominant phenotype in affected family members was a secundum ASD along with atrioventricular conduction abnormalities. Since then, a range of cardiac abnormalities, including VSD, tetralogy of Fallot (TOF), pulmonary valve atresia, subvalvular aortic stenosis, and Ebstein's anomaly have been correlated with heterozygous NKX2-5 mutations (Stallmeyer et al. 2010; Ellesøe et al. 2016). Heterozygous Nkx2-5 knockout mice displayed a spectrum of cardiac developmental phenotypes that are dependent on the genetic background. In the FVB/N and $129 / \mathrm{Sv}$ backgrounds, $N k \times 2-5^{+/-}$mice have PFO, atrial septal aneurysms, and BAV with aortic stenosis (Biben et al. 2000), whereas $N k \times 2-5^{+/-}$mice in C57Bl/6 background show a high incidence $(\sim 40 \%)$ of secundum ASD and both muscular and membranous VSD (Fig. 1A,D,E,G,H; Winston et al. 2010). Additional mice harboring specific human disease-associated variants in Nkx2-5 have also been reported and they display a spectrum of cardiac phenotypes that mimic human disease (Ashraf et al. 2014; Chowdhury et al. 2015; Zakariyah et al. 2017).

\section{GATA4}

A similar human genetics approach used for TBX5 and NKX2-5 led to the discovery that heterozygous mutations in GATA4 caused cardiac septation defects, primarily secundum ASD and membranous VSD (Garg et al. 2003). Multiple disease-causing, likely loss-of-function genetic variants in GATA4 have been reported for a range of cardiac defects, including AVSD, pulmonic valve stenosis, and TOF (Okubo et al. 2004; Hirayama-Yamada et al. 2005; Sarkozy et al. 2005; Nemer et al. 2006; Schluterman et al. 2007). Mice harboring a mutant Gata4 allele $\left(\right.$ Gata $\left.^{\mathrm{Aex2} / W T}\right)$ were generated in which the start codon and almost half of the coding region is deleted (Rajagopal et al. 2007), whereas mice heterozygous for this allele display no cardiac phenotypes in a mixed genetic background, when bred into C57Bl6 background display 50\% perinatal lethality. Analysis of Gata $4^{\Delta \operatorname{exz} / W T} \mathrm{em}-$ bryonic hearts identified CHD in 76\%, including 
U. Majumdar et al.

AVSD; primum and secundum ASD; inlet, membranous, and muscular VSD; and right ventricular hypoplasia (Fig. 1B,C,F,I). The incidence of CHD decreased to $30 \%$ when this mutant allele was backcrossed into an FVB genetic background. Mice harboring a human CHDsegregating mutation (G296S) in GATA4 have also been reported and display a PFO in $80 \%$ of adult mice along with stenosis of the aortic and pulmonic valves at a lower penetrance (Misra et al. 2012; LaHaye et al. 2019).

In combination, these models of a common form of CHD have provided important insights for in vivo modeling of human CHD. First, the mouse model recapitulates structural malformations found in humans. Second, these models showed that one genetic mutation could result in multiple cardiac abnormalities, a septation defect and atrioventricular block with mutations in NKX2-5 or TBX5, and a septation defect and pulmonary valve stenosis with a GATA4 mutation. Another important point was the variability of phenotypes found in these murine models with alterations in the genetic background supporting the role of modifier genes. Finally, an interesting observation that was suggested is that PFO, which is present in $10 \%-25 \%$ of the population (Fisher et al. 1995; Homma et al. 2016), may represent a mild form of ASD and therefore may also have genetic contributors.

\section{MURINE MODELS OF CARDIAC VALVE MALFORMATIONS}

Proper development of heart valves is important for unidirectional blood flow in humans and other species with chambered hearts. Congenital valve malformations are the most frequent type of $\mathrm{CHD}$ and $\mathrm{BAV}$ is the most common with a population prevalence of $1.3 \%$ (Verma and Siu 2014). In BAV, there is improper septation or fusion of two of the three aortic leaflets (right coronary, left coronary, and noncoronary) (Fig. 2) and is associated with the development of adult-onset complications, including aortic valve stenosis (AVS) and regurgitation, calcific aortic valve disease (CAVD), and aortopathy. BAV can be subdivided into three morphologic categories: R-L (fusion of right and left coronary leaflets), which is most common in humans; R-NC (fusion of right and noncoronary); and L-NC (fusion of left and noncoronary). In addition, congenital stenosis of the aortic or pulmonic valve are common types of CHD. For each of these conditions, genetic etiologies in humans have been described and murine models developed (Table 1 ).

\section{$\mathrm{NOTCH} 1$}

By studying multigenerational families with autosomal-dominant inherited cardiac disease, pathologic loss-of-function sequence variants in NOTCH1 were the first reported genetic cause of BAV and its associated aortic disease (Garg et al.2005). Since then, other groups have also identified different NOTCH1 mutations that cause $\mathrm{BAV}$, other forms of left-sided CHD and TOF (McBride et al. 2008; Kerstjens-Frederikse et al. 2016; Page et al. 2019). Mice heterozygous for Notch1 display minimal aortic disease with a low incidence of BAV and mild CAVD (Nigam and Srivastava 2009; Nus et al. 2011; Bosse et al. 2013). The BAV phenotype is more penetrant with complete deletion of Notch 1 from valve endothelial cells (after endocardial to mesenchymal transformation) using $N f a t c 1^{\text {enCre }}$ as these mice display an $\sim 30 \%$ incidence of R-L BAV by one group (Fig. 2A-D) but other investigators reported both R-L and R-NC BAV (MacGrogan et al. 2016; Wang et al. 2017). In addition, the analysis of $\mathrm{Notch}^{+/-}$mice lacking telomerase activity by genetic deletion of Terc (telomerase RNA component; $m T R$ ) displayed robust CAVD with associated AVS (Theodoris et al. 2017). Similarly, the generation of Notch $1^{+/-}$mice in the setting of complete deletion of endothelial nitric oxide synthase $\left(\mathrm{Nos}^{-1-}\right)$ resulted in high incidence of BAV with associated AVS and regurgitation and molecular changes consistent with CAVD (Bosse et al. 2013). Interestingly, Nos3 $^{-/-}$; Notch1 $1^{+-}$mice display significant perinatal lethality, which was because of TOFlike phenotypes (Koenig et al. 2016). The role of genetic background in murine models has also been seen with Notch $1^{+/-}$mice, where dilation of the aortic root is found when backcrossed into a 129SvEv strain (Koenig et al. 2017). 
A
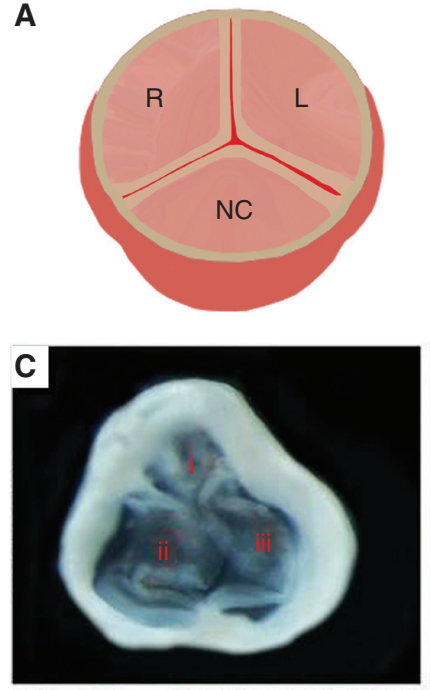

Wild-type

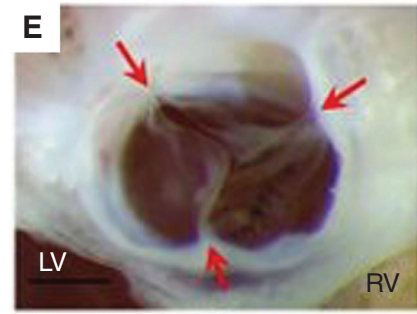

Wild-type
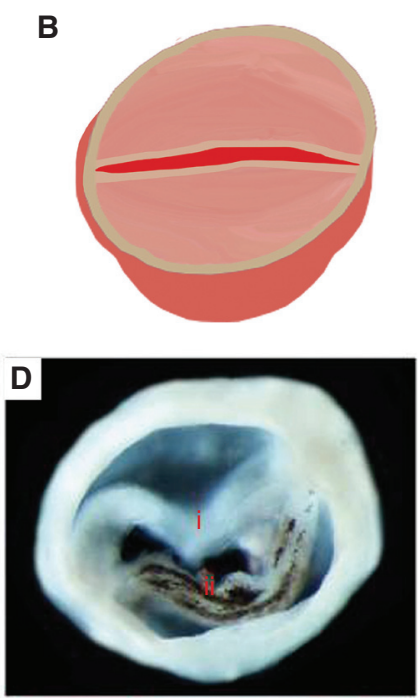

Nfatc1enCre; Notch $1^{f / / f l}$

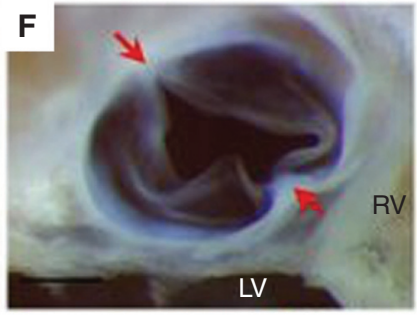

Gata5 $5^{-/}$

Figure 2. Mouse models for aortic valve malformations. Illustrations represent a tricuspid aortic valve $(A)$ and a bicuspid aortic valve (BAV) $(B)$. Right (R), left (L), and noncoronary (NC) leaflets are labeled. BAVs were shown in endothelial-specific deletion of Notch1 $\left(\mathrm{Nfatc1}^{\text {enCre }}\right.$; Notch1 $\left.{ }^{f l f l}\right)(D)$ and in Gata5 ${ }^{-l-}(F)$ mice compared with normal three leaflet structure found in wild-type mice $(C, E)$. (LV) left ventricle, $(R V)$ right ventricle. (Panels $C$ and $D$ are reprinted from Wang et al. 2017, with permission, from Oxford University Press (c) 2017. Panels $E$ and $F$ are reprinted from Laforest et al. 2011, with permission, from the American Society for Clinical Investigation (c) 2011.)

\section{GATA5 and GATA6}

In addition to NOTCH1, GATA5-a member of the GATA family of transcription factors-has also been implicated in BAV where predicted damaging sequence variants in GATA5 have been identified in affected individuals by several investigators (Padang et al. 2012; Bonachea et al. 2014; Shi et al. 2014). Genetic deletion of Gata5 in mice led to a partially penetrant R-NC BAV phenotype (25\%) with associated valve stenosis (Fig. 2E,F; Laforest et al. 2011). Further studies revealed that endothelial cell-specific deletion of Gata5 using Tie2-Cre in a mixed genetic background (129SV/C57Bl6) recapitulated the R-NC BAV (21\%) phenotype of Gata5 ${ }^{-/-}$ mice. Of note, BAV identified in humans with GATA5 variants had both R-NC and R-L BAV. Similar to NOTCH1, disease-causing variants in GATA5 have been reported in a spectrum of CHD (Jiang et al. 2013; Wei et al. 2013; Kassab et al. 2016).

Interestingly another member of the GATA transcription factor family has also been implicated in BAV. Whereas mutations in GATA6 are implicated as a cause of truncus arteriosus (TA) 
U. Majumdar et al.

and identified in patients with septal defects and TOF, murine models display a BAV phenotype (Kodo et al. 2009; Maitra et al. 2010). Mice haploinsufficient for Gata6 display $56 \%$ incidence of BAV in males and 27\% incidence in females owing to R-L fusion. Further analysis revealed that second heart field (SHF)-specific deletion of Gata6 using Isl1-Cre mice can recapitulate the BAV phenotype indicating SHF-specific role for Gata6 in valve development (Gharibeh et al. 2018). The conotruncal heart defects identified in humans are only found in $\mathrm{Gata4}^{+/-}$; $\mathrm{Gata5}^{+/-}$ and Gata5 $^{+/-} ;$Gata6 $^{+/-}$murine embryos, as they display double-outlet right ventricle (DORV) and overriding aorta (Laforest and Nemer 2011).

These mouse models of BAV provided important tools to gain insight into the disease. First, generation of murine models of R-L and R-NC BAV imply that these phenotypes have distinct embryologic origins and clinical observations have suggested that they have unique long-term comorbidities (Mahadevia et al. 2014). These murine models also display the common complications of BAV, which include CAVD and aortopathy. Accordingly, the models will serve as important tools that can be used to study the mechanisms of disease progression and potentially test novel therapies. A final observation is the genotype-phenotype discrepancy in leaflet fusion phenotype found in mouse models versus humans with corresponding genetic mutations.

\section{MURINE MODELS OF CONOTRUNCAL AND AORTIC ARCH ARTERY DEFECTS}

Malformations of the cardiac outflow tract and aortic arch include a range of CHD from TOF, DORV, and TA to interrupted aortic arch (IAA) (Fig. 3). The etiology for majority of conotruncal and aortic arch defects remains unknown; however, a known genetic risk factor is $22 \mathrm{q} 11$ microdeletion, which accounts for $\sim 12 \%$ of conotruncal heart defects (Momma 2010).

\section{2q11 Deletion Syndrome/TBX1/CRKL}

Approximately $75 \%$ of patients with $22 \mathrm{q} 11$ deletion syndrome (22q11DS), who commonly harbor an $\sim 3 \mathrm{Mb}$ heterozygous deletion of chromosome 22q11.2, are born with CHD, primarily conotruncal heart defects and aortic arch anomalies (Yamagishi and Srivastava 2003). Identifying the causative gene for CHD associated with 22q11DS was an important step in the investigation of genetic and developmental basis for CHD. Although molecular genetic studies revealed that $>40$ genes resided in the crucial 22q11.2 locus, direct sequencing of candidate genes failed to detect mutations in non-deleted patients with 22q11DS phenotypes (Lindsay 2001). Therefore, mouse models for 22q11DS were generated by creating orthologous chromosomal deletions. By using this genetically engineered mouse $(D f 1)$, which harbored a heterozygous deletion of the orthologous 22q11 region, investigators were successful in reproducing aortic arch abnormalities and some conotruncal heart defects in $D f 1 /+$ mice that recapitulated those in human 22q11DS (Lindsay et al. 1999). Subsequent studies showed pathogenic variants in TBX1, a gene located in chromosome 22q11.2, as the cause of cardiovascular defects that occur in 22q11DS (Lindsay et al. 2001; Merscher et al. 2001).

Heterozygosity of $T b x 1$ caused aortic arch anomalies, whereas homozygosity of $T b x 1$ led to most of the phenotypes observed in 22q11DS, including not only conotruncal and aortic arch defects but also thymic hypoplasia, parathyroid hypoplasia, cleft palate, and abnormal facial features that are characteristic of this syndrome (Hu et al. 2004; Zhang and Baldini 2008). Several animal models with mutant Tbx1 alleles have also been generated (Table 1). Homozygous $T b x 1$ null mouse embryos are associated with $100 \%$ neonatal lethality with cardiovascular defects including conotruncal heart defects. However, mice harboring hypomorphic alleles of $T b x 1$ that express varying levels of Tbx1 display a range of defects including TOF, DORV, TA, and IAA (Fig. 3D-J; Hu et al. 2004; Zhang and Baldini 2008).

CRKL, a gene encoding CRK-like proto-oncogene, adaptor protein also maps within the commonly deleted region for 22q11DS. Mice homozygous for a targeted null mutation at Crkol locus $\left(\mathrm{Crkol}^{-/-}\right)$showed abnormal aortic 


\section{A}

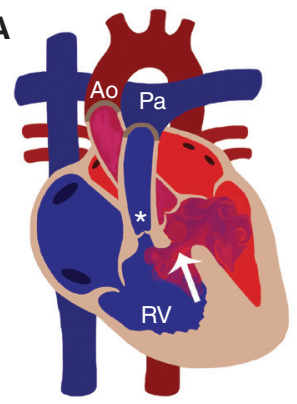

D

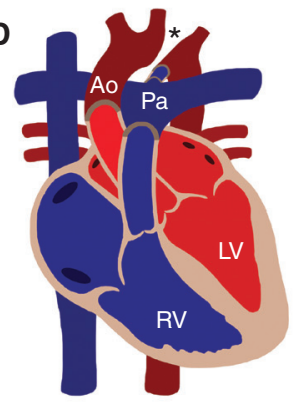

G

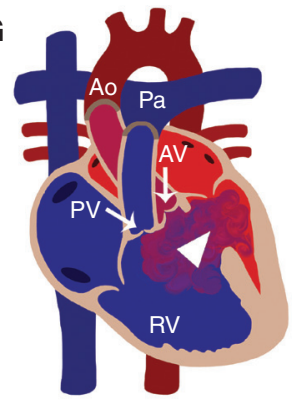

I

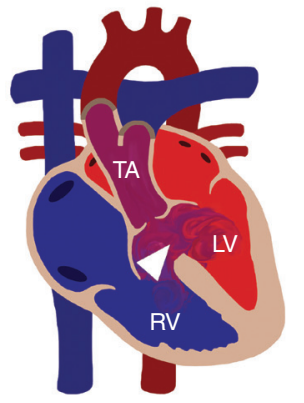

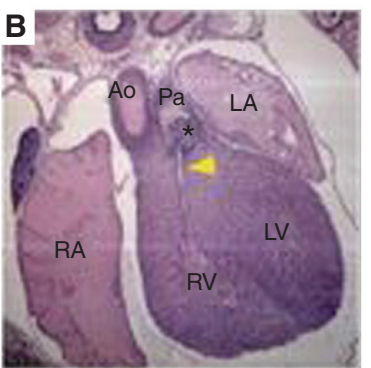

$\mathrm{Crkol}^{-/-}$
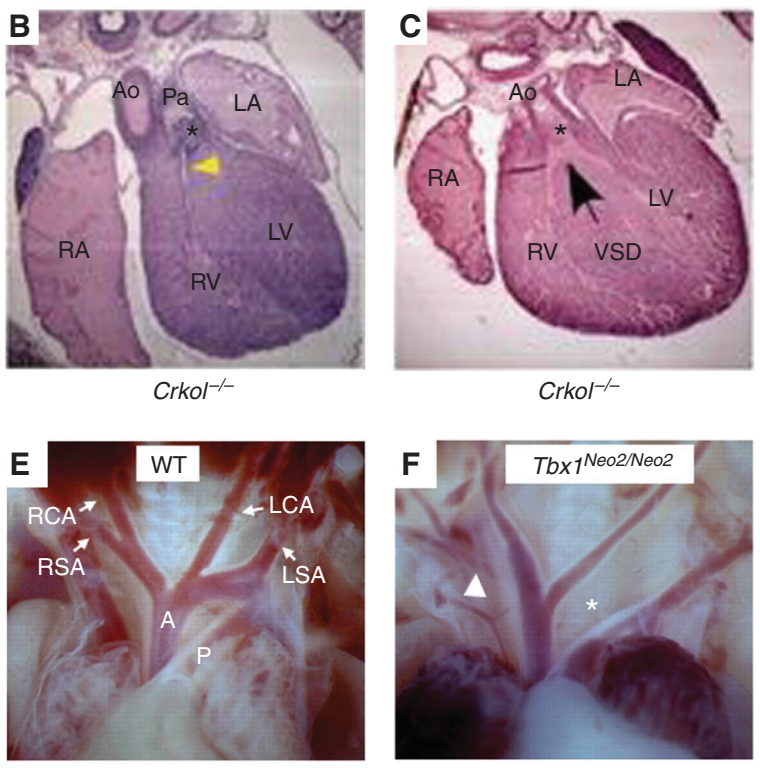

$\mathrm{Crkol}^{-/-}$
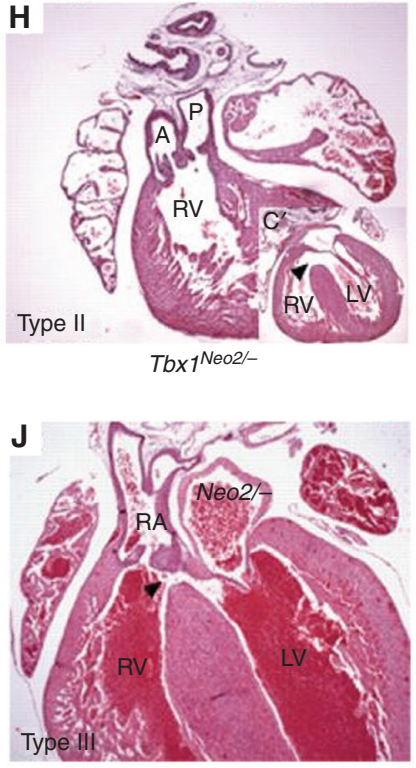

$\mathrm{Tb}^{\mathrm{N}} \mathrm{T}^{\mathrm{Neo} 2 /}$

Figure 3. Murine models for conotruncal and aortic arch artery defects. (A) Diagram illustrates tetralogy of Fallot (TOF), characterized by right ventricular hypertrophy, ventricular septal defect (VSD) (arrow), stenosis of pulmonary valve, and subvalvar area $\left({ }^{*}\right)$ in human heart. Comparable TOF phenotype was observed in mouse model of $\mathrm{Crkol}^{-1-}$ at embryonic day 16.5 shown in $B$ and $C$. $(D, F)$ Interrupted aortic arch (IAA) $\left(^{*}\right)$ detected in human patients were recapitulated in $\mathrm{Tb} \times 1^{\mathrm{Neo} 2 / \mathrm{Neo} 2}$ mouse model at E18.5 compared with wild-type (WT) mouse $(E)$. (G,I) Representative diagram of a diseased heart display double-outlet right ventricle (DORV) and truncus arteriosus (TA) with VSD (arrow head) $(G, I)$. Similar phenotypes were observed in $\mathrm{Tb} x 1^{\mathrm{Neo} 2 / \mathrm{Neo} 2}$ mice $(H, J)$ at E18.5. Inset $\mathrm{C}$ in $H$ shows VSD. (RA) right atrium, (RV) right ventricle, (LA) left atrium, (LV) left ventricle, (AV) aortic valve, (Ao/A) aorta, $(\mathrm{Pa} / \mathrm{P})$ pulmonary artery, (RCA) right coronary artery, (LCA) left coronary artery, (RSA) right subclavian artery, (LSA) left subclavian artery, (PV) pulmonary valve. (Panels $B$ and $C$ are reprinted from Guris et al. 2001, with permission, from Springer Nature @ 2001. Panels $E, F, H$, and $J$ are reprinted from Zhang and Baldini 2008, with permission, from Oxford University Press @ 2007.) 
U. Majumdar et al.

arteries and malalignment of the outflow tract including IAA, overriding aorta, and DORV (Fig. 3A-C; Guris et al. 2001). Although TBX1 is considered to be the major genetic determinant for several phenotypes associated with 22q11DS, CRKL may also play a role (Guris et al. 2006; Moon et al. 2006).

Moreover, novel therapeutic strategies have been proposed using Tbx1 mutant mouse models. Canonical $W n t / \beta$-catenin has major roles in cardiac outflow tract development that may act upstream of Tbx1. By gene expression profiling, Tbx1 and $\beta$-catenin were found to have opposing effects on anterior heart field (AHF) differentiation and consistent with this, genetic rescue experiments between Tbx 1 and $\beta$-catenin in the AHF found that TA observed in Tbx1 conditional null embryos was partially rescued by loss of one allele of the $\beta$-catenin gene in the Mef2c-AHF-Cre domain (Racedo et al. 2017). Although these genetic approaches are important, it is difficult to translate them to the clinical setting. A recent study using a high-throughput screening approach identified vitamin B12 as a molecule capable of enhancing Tbx1 gene expression (Lania et al. 2016). Using Tbx $1^{\text {lacZ/+ }}$ mice as a readout, vitamin B12 was shown to increase expression of $T b x 1$ in vivo and partially rescue the $T b x 1$ haploinsufficient phenotype.

\section{FOXC1, FOXC2, FOXH1 (Forkhead Transcription Factors)}

The forkhead transcription factors Foxc1, Foxc2, and Foxh1 have been shown to recognize and bind to cis-regulatory elements in Tbx1 promoter and directly promote $T b x 1$ expression (Maeda et al. 2006). Mutations in FOXC1, FOXC2, and FOXH1 were identified in patients with TOF (Roessler et al. 2008; Töpf et al. 2014). Mice null for Foxc1 have coarctation of the aorta and aortic and pulmonary valve dysplasia as well as IAA type B, whereas Foxc2-null mice have IAA type A and type B (Winnier et al. 1999). In addition, Foxc1 and Foxc 2 compound mutant mice also show coarctation of the aorta, aortic and pulmonary valve dysplasia, and IAA type A and B (Winnier et al. 1999). Mice deficient for Foxh1, which mediates Nodal signaling, show defects in anterior-posterior patterning and in node formation (Yamamoto et al. 2001). Conditional deletion of Foxh1 in mice manifests severe conotruncal heart defects including transposition of the great arteries (TGA) and DORV (Yamamoto et al. 2003).

These studies show the utility of mouse models to generate models of CHD that involve malformations of multiple cardiovascular structures including cardiac septa, valves, and great vessels. In addition, they show the value of genetically engineered murine models to identify the CHD-causing genes within a contiguous gene deletion syndrome or pathologic copy number variation $(\mathrm{CNV})$. Last, they show how models can be used to define molecular mechanisms, which are then used to identify novel genetic or pharmacologic therapies that may ameliorate the severity of the CHD phenotype.

\section{MURINE MODELS OF COMPLEX CONGENITAL HEART DEFECTS}

The development of murine models, which mimic the complex forms of CHD, have been more difficult to develop. Most success has been obtained with heterotaxy syndrome, which is linked to mutation of genes involved in cilia morphogenesis. A classic example of this is the genetic association with mutations in ZIC3, which encodes a gene downstream of the left-right signaling pathway, in patients with X-linked heterotaxy (D'Alessandro et al. 2013). Consistent with the human phenotype mice, null for Zic3 and those harboring a hypomorphic allele show the spectrum of left-right patterning cardiac defects including TGA, single ventricle/ DORV, AVSD, and abnormal systemic venous connections along with other neural tube and skeletal malformations (Purandare et al. 2002; Haaning et al. 2013). Numerous genetic murine models of left-right patterning defects have also been reported that recapitulate human disease (Pierpont et al. 2018).

Another major subtype of left-sided human CHD is hypoplastic left heart syndrome (HLHS). HLHS is a severe form of CHD that accounts for $4 \%-8 \%$ of all CHD, and is characterized by hypoplasia of the left ventricle, aorta, 
and other left-sided cardiac structures including atresia or stenosis of both the aortic and mitral valves (Fig. 4). In spite of significant advances in the management of HLHS, mortality and morbidity remain significant, and its etiology is not well understood. Although genetic syndromes such as Turner and Jacobsen syndrome are associated with HLHS, the role of individual genes are unknown. Mouse knockouts of Hand1 and Hand2-transcription factors expressed in developing ventricles-have provided critical insights in ventricular morphogenesis but they were unable to replicate the HLHS phenotype (McFadden et al. 2005). As no major genetic driver for HLHS has yet been identified, no monogenetic animal model for HLHS exists to study its molecular basis and an oligogenic etiology has been proposed (McBride et al. 2005).

A recent study described HLHS in mutant mice and the identification of genes causing HLHS (Liu et al. 2017). Mutations in Sap130, which encodes Sin3A-associated protein in the histone deacetylase complex, and Pcdha9, which encodes the cell-adhesion protein protocadherinA9, were validated by CRISPR-Cas9 genome editing in mice, revealing digenic etiology for
HLHS. They also identified one individual with HLHS who harbored SAP130 and PCDHA13 mutations. Twenty-six percent of Sap $130^{\mathrm{m} / \mathrm{m}}$; Pcdha9 $9^{\mathrm{m} / \mathrm{m}}$ mutant mice show phenotypes associated with HLHS in which Sap130 mediates left ventricular hypoplasia, and Pcdha9 increases penetrance of aortic valve abnormalities, suggesting synergistic interactions between Sap130 and Pcdha9 mutations resulting in HLHS (Fig. 4). Of note, a subset of the embryos displayed DORV with hypoplastic left ventricle as opposed to the strict morphologic definition of HLHS. These studies raise the question of whether digenic or oligogenic murine models will need to be developed to accurately recapitulate some of these more complex forms of CHD.

\section{OTHER APPROACHES FOR GENETIC MODELING OF CONGENITAL HEART DISEASE}

Rapid advancements in next-generation sequencing approaches have aided in the discovery of novel etiologies for CHD. The NHLBIfunded Pediatric Cardiac Genomics Consortium (PCGC) and an international study led
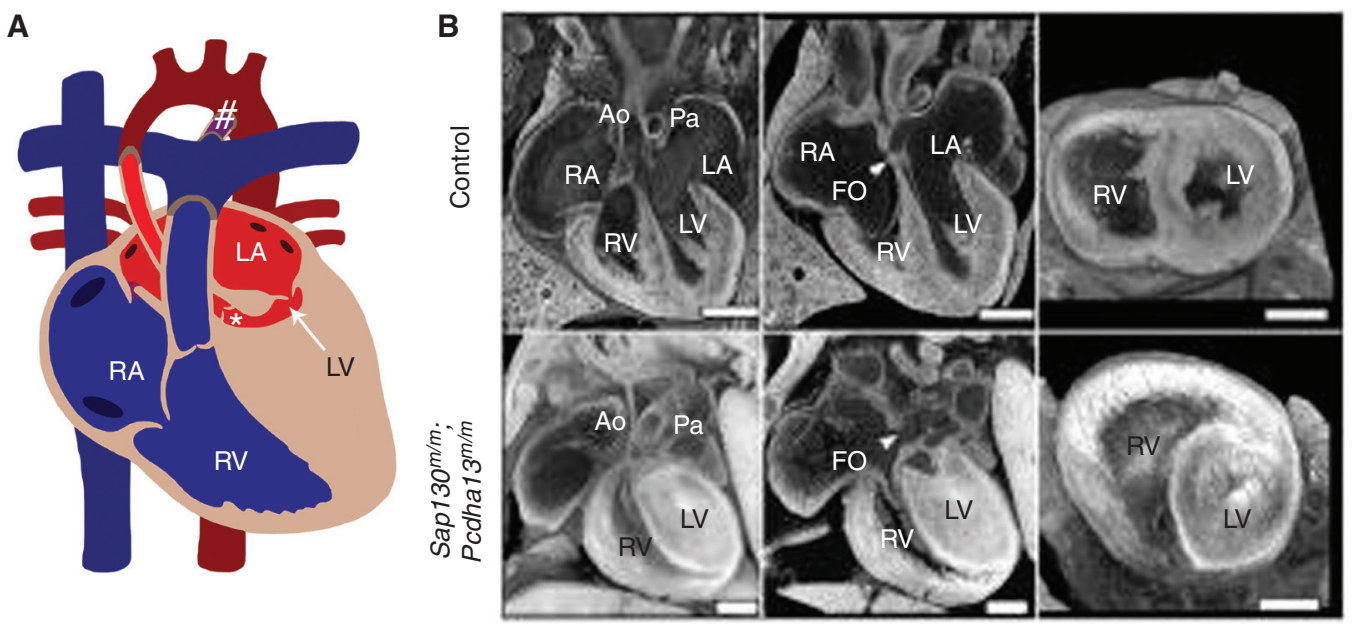

Figure 4. Model for hypoplastic left heart syndrome (HLHS). (A) Diagram represents a heart with HLHS, characterized by small/hypoplastic left ventricle (arrow), aorta $\left(^{*}\right)$, and patent ductus arteriosus (PDA) (\#). (B) Represents similar features of HLHS phenotype in mouse model of Sap $130^{\mathrm{m} / \mathrm{m}}$; Pcdha1 $3^{\mathrm{m} / \mathrm{m}}$ compared with littermate controls at postnatal day $0(\mathrm{P} 0)$. Scale bars, $0.5 \mathrm{~mm}$. (RA) right atrium, (RV) right ventricle, (LA) left atrium, (LV) left ventricle, (Ao) aorta, $(\mathrm{Pa})$ pulmonary artery, $(\mathrm{FO})$ foramen ovale. (Panel $B$ is reprinted from Liu et al. 2017, with permission, from Springer Nature (C) 2017.) 
U. Majumdar et al.

by the Welcome Trust have performed wholeexome sequencing of nearly 5000 individuals with CHD (Sifrim et al. 2016; Jin et al. 2017). These studies have uncovered numerous potential CHD-causing genes, estimated to be $\sim 400$, which does not incorporate the potential different variants within each gene that may have differential effects. Accordingly, the sheer number of variants requires genetic models that allow for a higher throughput analysis. Along these lines, the zebrafish and the fruit fly have emerged as in vivo models and iPSCs as in vitro models, and the details of each are discussed below.

\section{Zebrafish and Fruit Fly}

The zebrafish (D. rerio) is an important vertebrate model to study cardiovascular disease. In the two-chambered zebrafish heart, deoxygenated blood flows through single atrium and ventricle, which pumps blood through the gills for oxygenation. Despite the anatomic differences between the two-chambered zebrafish and four-chambered mammalian heart, several studies have indicated similar gene regulatory networks driving cardiogenesis (Asnani and Peterson 2014). Eighty-two percent of human disease-related genes (listed in OMIM) have at least one ortholog in zebrafish and these are well suited for genetic manipulation as well as morpholino-induced gene knockdown to simulate human cardiac disease (Howe et al. 2013). In addition, zebrafish larvae are transparent, which allows easy visualization of the heart and vasculature during development (Brown et al. 2016). The zebrafish model has already been used to model cardiac phenotypes associated with genes implicated in nonsyndromic (e.g., GATA4, GATA6, MYH6, NKX2-5, and TBX20) and syndromic CHD (e.g., PTPN11, NIPBL, CHD7, $T B X 1$, and TBX5) (reviewed in Grant et al. 2017). Although the exact cardiac morphologic phenotypes are not often recapitulated, these high-throughput studies highlight the ability for this model to screen for potential disease genes and genetic variants.

A relatively simple organism, the fruit fly (D. melanogaster), is also being used in genetic studies. Although it is difficult to directly com- pare fly developmental defects with specific CHD subtypes, this can serve as a testing platform for disease-associated genes identified from patient genomic sequencing. Functional homologs of $75 \%$ of human disease-associated genes are also represented in the fly genome (Reiter et al. 2001). In a recent study, a cardiac-specific 4XHand-Gal4 driver was combined with fly lines carrying UAS-Gene-IR RNAibased silencing constructs to examine cardiac structure and function for fly homologs. Among 134 candidate disease genes published by the PCGC, 52\% of these homologs showed their involvement in cardiac development and function in flies (Zhu et al. 2017a). In addition, the Drosophila model system may be useful to test for gene-gene interactions that are important for heart formation, which may be useful in attempts to define the oligogenic nature of complex CHD (as discussed above) (Vogler and Bodmer 2015).

\section{Induced Pluripotent Stem Cells}

Various studies based on transgenic mouse models have verified genes involved in cardiac development. However, complete deletion of a gene is often required to generate cardiac phenotypes in the mouse model, which does not reflect the pathogenic point mutation and haploinsufficiency commonly observed in human CHD (Musunuru et al. 2018). Human iPSCs (hiPSCs) provide a unique in vitro platform to study human cells as they can be differentiated and expanded into multiple somatic cell types. When hiPSCs are derived from a patient, they not only carry the exact pathogenic mutation in the human genome but also the genetic background, which may serve as a modifier of the $\mathrm{CHD}$ phenotype. These properties have uniquely qualified the hiPSCs model to study human disease in a dish (Mital 2016). Additionally, introduction and/or correction of genetic variants is possible with the genome editing tools, which allows researchers to generate new disease models and determine therapeutic strategies for individuals. Initial progress has been made using hiPSCs for comprehensive understanding of cardiomyopathies, arrhythmias, vascular disor- 
ders, along with metabolic risk factors for ischemic heart disease (Musunuru et al. 2018).

As discussed above, mutations in GATA4 and NOTCH1 have been linked to cardiac septal defects and aortic valve disease, respectively. In both cases, patient-derived iPSCs have been used to define the underlying molecular mechanism for these diseases. Generation and analysis of iPSC-derived cardiomyocytes from patients with heterozygous GATA4 G296S missense mutation showed that the mutant cells displayed decreased contractility and abnormal calcium handling along with dysregulation of Shh signaling, a pathway implicated in cardiac septation that was recently shown to be downstream of Gata4 in mice (Hoffmann et al. 2009; Ang et al. 2016b; Zhou et al. 2017). They also used multiple genomic approaches to investigate the underlying mechanisms. As anticipated, they found a disruption of the cooperative regulation of a cardiac gene program mediated by Gata 4 and Tbx 5 but surprisingly also noted an up-regulation of an endocardial/endothelial gene program, showing the multitude of cellular effects from a single point mutation. A similar approach was used to investigate $\mathrm{NOTCH} 1 \mathrm{mu}-$ tations, in which iPSC-derived endothelial cells from patients with $\mathrm{NOTCH} 1$ mutations were examined. Using an in vitro model of vascular shear stress, these mutant cells failed to activate antiosteogenic, anti-inflammatory, and antioxidant pathways that were induced in control cells (Theodoris et al. 2015). This observation was consistent with observed susceptibility toward calcification of the BAV. Supravalvular aortic and pulmonary artery stenosis can occur because of mutations in ELN (elastin) or as part of Williams-Beuren syndrome, a contiguous gene deletion syndrome at chromosome 7q11.23 where ELN resides. Disease-causing mutations in ELN were modeled using hiPSCderived smooth muscle cells (SMCs) and showed less differentiated SMCs, with impaired formation of actin filaments and vascular tubes, along with increased proliferation rates (Ge et al. 2012; Kinnear et al. 2013). The generation of these cellular models for NOTCH1 and ELN mutation-mediated disease have resulted in a novel tool to screen for novel pharmacologic therapies.
Apart from monogenic diseases, hiPSC studies are also important to delineate complex CHD caused by multiple genetic and environmental factors, such as HLHS. Accordingly, investigators have generated iPSC-derived cardiomyocytes from patients with HLHS and found that these cells display a diminished yield of cardiomyocytes, a reduced beating rate, disorganized sarcomeres, and sarcoplasmic reticulum along with down-regulation of $\mathrm{NOTCH}$ signaling components, which were interestingly rescued by nitric oxide stimulation (Jiang et al. 2014; Hrstka et al. 2017; Yang et al. 2017). Together, these observations show the advantages of iPSCs as an in vitro model to understand cellular events leading to morphogenetic defects along with generating an important tool to investigate new therapies. In addition, iPSC cells may serve as a promising strategy for the functional examination of the predicted diseasecausing variants in the noncoding genome that are identified from whole-genome sequencing approaches in the CHD population.

\section{CONCLUDING REMARKS}

With the sequencing of human genome and technological advances in genome analysis, there has been the discovery of numerous monogenic causes of nonsyndromic and syndromic CHD. While cardiac defects span a spectrum of malformations involving the four-chambered heart, genetic manipulation of mice has been successful in recapitulating these phenotypes from septation defects and valve abnormalities to conotruncal heart defects. These models have served to define disease mechanisms and have also allowed for a better understanding of genotype-phenotype correlations and the importance of modifiers that result in phenotypic variability. In addition, novel gene-environment effects have been discovered in which maternal exercise is able to rescue the ASD phenotype in Nkx2-5 haploinsufficient mice, and Notch1 haploinsufficient embryos exposed to maternal diabetes display a highly penetrant VSD phenotype (Schulkey et al. 2015; Basu et al. 2017). Also, for mice that survive to adulthood, they allow for investigation into the role of cardiac develop- 
U. Majumdar et al.

mental genes in adult-onset cardiovascular complications.

The recent large-scale sequencing efforts in human $\mathrm{CHD}$ have also shown its complex genetic architecture. These studies have frequently identified likely pathogenic $\mathrm{CNV}$ and rare and predicted pathogenic sequence variants in children with CHD. For the majority of cases, the functional significance of the proposed candidate genes and genetic variants in causing $\mathrm{CHD}$ is unknown. Accordingly, analysis of this large number of genetic abnormalities is not amenable using the murine model system, which has been the gold standard. Therefore, it will be important to use additional in vivo (fruit fly and zebrafish) and in vitro (iPSC) model systems to functionally characterize these potentially pathologic variants. Ultimately as the field moves forward, it may be necessary to generate larger animal models of $\mathrm{CHD}$ (i.e., pig) using gene-editing techniques (Ryu et al. 2018), as this will allow for surgical correction of these defects and long-term studies to better understand the mechanisms of disease found in adult CHD survivors.

\section{ACKNOWLEDGMENTS}

We thank Dr. Madhumita Basu for critical review of the manuscript. V.G. is supported by funding from the Abigail Wexner Research Institute at Nationwide Children's Hospital and grants from the National Institutes of Health (R01HL121797 and R01HL132801). J.Y. is supported by funding from the Japan Heart Foundation/Bayer Yahukin Research Grant Abroad.

\section{REFERENCES}

Akhirome E, Walton NA, Nogee JM, Jay PY. 2017. The complex genetic basis of congenital heart defects. Circ J 81: 629-634. doi:10.1253/circj.CJ-16-1343

Ang SY, Uebersohn A, Spencer CI, Huang Y, Lee JE, Ge K, Bruneau BG. 2016a. KMT2D regulates specific programs in heart development via histone H3 lysine 4 di-methylation. Development 143: 810-821. doi:10.1242/dev .132688

Ang YS, Rivas RN, Ribeiro AJS, Srivas R, Rivera J, Stone NR, Pratt K, Mohamed TMA, Fu JD, Spencer CI, et al. 2016b. Disease model of GATA4 mutation reveals transcription factor cooperativity in human cardiogenesis. Cell 167: 1734-1749.e22. doi:10.1016/j.cell.2016.11.033

Araki T, Mohi MG, Ismat FA, Bronson RT, Williams IR, Kutok JL, Yang W, Pao LI, Gilliland DG, Epstein JA, et al. 2004. Mouse model of Noonan syndrome reveals cell type- and gene dosage-dependent effects of Ptpn11 mutation. Nat Med 10: 849-857. doi:10.1038/nm1084

Ashraf H, Pradhan L, Chang EI, Terada R, Ryan NJ, Briggs LE, Chowdhury R, Zarate MA, Sugi Y, Nam HJ, et al. 2014. A mouse model of human congenital heart disease: high incidence of diverse cardiac anomalies and ventricular noncompaction produced by heterozygous Nkx2-5 homeodomain missense mutation. Circ Cardiovasc Genet 7: 423-433. doi:10.1161/CIRCGENETICS.113.000281

Asnani A, Peterson RT. 2014. The zebrafish as a tool to identify novel therapies for human cardiovascular disease. Dis Model Mech 7: 763-767. doi:10.1242/dmm .016170

Bakkers J. 2011. Zebrafish as a model to study cardiac development and human cardiac disease. Cardiovasc Res 91: 279-288. doi:10.1093/cvr/cvr098

Bamforth SD, Bragança J, Eloranta JJ, Murdoch JN, Marques FI, Kranc KR, Farza H, Henderson DJ, Hurst HC, Bhattacharya S. 2001. Cardiac malformations, adrenal agenesis, neural crest defects and exencephaly in mice lacking Cited2, a new Tfap2 co-activator. Nat Genet 29: 469-474. doi:10.1038/ng768

Basson CT, Cowley GS, Solomon SD, Weissman B, Poznanski AK, Traill TA, Seidman JG, Seidman CE. 1994. The clinical and genetic spectrum of the Holt-Oram syndrome (heart-hand syndrome). N Engl J Med 330: 885891. doi:10.1056/NEJM199403313301302

Basson CT, Bachinsky DR, Lin RC, Levi T, Elkins JA, Soults J, Grayzel D, Kroumpouzou E, Traill TA, Leblanc-Straceski J, et al. 1997. Mutations in human TBX5 [corrected] cause limb and cardiac malformation in Holt-Oram syndrome. Nat Genet 15: 30-35. doi:10.1038/ng0197-30

Basson CT, Huang T, Lin RC, Bachinsky DR, Weremowicz S, Vaglio A, Bruzzone R, Quadrelli R, Lerone M, Romeo G, et al. 1999. Different TBX5 interactions in heart and limb defined by Holt-Oram syndrome mutations. Proc Natl Acad Sci 96: 2919-2924. doi:10.1073/pnas.96.6.2919

Basu M, Zhu JY, LaHaye S, Majumdar U, Jiao K, Han Z, Garg V. 2017. Epigenetic mechanisms underlying maternal diabetes-associated risk of congenital heart disease. JCI Insight 2: 95085. doi:10.1172/jci.insight.95085

Biben C, Weber R, Kesteven S, Stanley E, McDonald L, Elliott DA, Barnett L, Köentgen F, Robb L, Feneley M, et al. 2000. Cardiac septal and valvular dysmorphogenesis in mice heterozygous for mutations in the homeobox gene Nkx2-5. Circ Res 87: 888-895. doi:10.1161/01.RES.87.10 .888

Bonachea EM, Chang SW, Zender G, LaHaye S, FitzgeraldButt S, McBride KL, Garg V. 2014. Rare GATA5 sequence variants identified in individuals with bicuspid aortic valve. Pediatr Res 76: 211-216. doi:10.1038/pr.2014.67

Bosse K, Hans CP, Zhao N, Koenig SN, Huang N, Guggilam A, LaHaye S, Tao G, Lucchesi PA, Lincoln J, et al. 2013. Endothelial nitric oxide signaling regulates Notch1 in aortic valve disease. J Mol Cell Cardiol 60: 27-35. doi:10 $.1016 /$ j.yjmcc.2013.04.001 
Brown DR, Samsa LA, Qian L, Liu J. 2016. Advances in the study of heart development and disease using Zebrafish. $J$ Cardiovasc Dev Dis 3: 13. doi:10.3390/jcdd3020013

Bruneau BG, Logan M, Davis N, Levi T, Tabin CJ, Seidman JG, Seidman CE. 1999. Chamber-specific cardiac expression of Tbx5 and heart defects in Holt-Oram syndrome. Dev Biol 211: 100-108. doi:10.1006/dbio.1999.9298

Bruneau BG, Nemer G, Schmitt JP, Charron F, Robitaille L, Caron S, Conner DA, Gessler M, Nemer M, Seidman CE et al. 2001. A murine model of Holt-Oram syndrome defines roles of the T-box transcription factor Tbx 5 in cardiogenesis and disease. Cell 106: 709-721. doi:10 .1016/S0092-8674(01)00493-7

Chowdhury R, Ashraf H, Melanson M, Tanada Y, Nguyen M, Silberbach M, Wakimoto H, Benson DW, Anderson RH, Kasahara H. 2015. Mouse model of human congenital heart disease: progressive atrioventricular block induced by a heterozygous $N k \times 2-5$ homeodomain missense mutation. Circ Arrhythm Electrophysiol 8: 1255-1264. doi:10.1161/CIRCEP.115.002720

D’Alessandro LC, Latney BC, Paluru PC, Goldmuntz E. 2013. The phenotypic spectrum of ZIC3 mutations in cludes isolated d-transposition of the great arteries and double outlet right ventricle. Am J Med Genet A 161A: 792-802. doi:10.1002/ajmg.a.35849

Durst R, Sauls K, Peal DS, deVlaming A, Toomer K, Leyne M, Salani M, Talkowski ME, Brand H, Perrocheau M, et al. 2015. Mutations in DCHS1 cause mitral valve prolapse. Nature 525: 109-113. doi:10.1038/nature14670

Ellesøe SG, Johansen MM, Bjerre JV, Hjortdal VE, Brunak S, Larsen LA. 2016. Familial atrial septal defect and sudden cardiac death: identification of a novel NKX2-5 mutation and a review of the literature. Congenit Heart Dis 11: 283290. doi:10.1111/chd.12317

Fisher DC, Fisher EA, Budd JH, Rosen SE, Goldman ME. 1995. The incidence of patent foramen ovale in 1,000 consecutive patients. A contrast transesophageal echocardiography study. Chest 107: 1504-1509. doi:10.1378/ chest.107.6.1504

Galvin KM, Donovan MJ, Lynch CA, Meyer RI, Paul RJ, Lorenz JN, Fairchild-Huntress V, Dixon KL, Dunmore $\mathrm{JH}$, Gimbrone MA Jr, et al. 2000. A role for smad6 in development and homeostasis of the cardiovascular system. Nat Genet 24: 171-174. doi:10.1038/72835

Garg V, Kathiriya IS, Barnes R, Schluterman MK, King IN, Butler CA, Rothrock CR, Eapen RS, Hirayama-Yamada $\mathrm{K}$, Joo K, et al. 2003. GATA4 mutations cause human congenital heart defects and reveal an interaction with TBX5. Nature 424: 443-447. doi:10.1038/nature01827

Garg V, Muth AN, Ransom JF, Schluterman MK, Barnes R, King IN, Grossfeld PD, Srivastava D. 2005. Mutations in NOTCH1 cause aortic valve disease. Nature 437: 27074 doi:10.1038/nature03940

Ge X, Ren Y, Bartulos O, Lee MY, Yue Z, Kim KY, Li W, Amos PJ, Bozkulak EC, Iyer A, et al. 2012. Modeling supravalvular aortic stenosis syndrome with human induced pluripotent stem cells. Circulation 126: 1695-1704. doi:10.1161/CIRCULATIONAHA.112.116996

Gharibeh L, Komati H, Bossé Y, Boodhwani M, Heydarpour M, Fortier M, Hassanzadeh R, Ngu J, Mathieu P, Body S, et al. 2018. GATA6 regulates aortic valve remodeling, and its haploinsufficiency leads to right-left type bicuspid aortic valve. Circulation 138: 1025-1038. doi:10.1161/ CIRCULATIONAHA.117.029506

Grant MG, Patterson VL, Grimes DT, Burdine RD. 2017. Modeling syndromic congenital heart defects in zebrafish. Curr Top Dev Biol 124: 1-40. doi:10.1016/bs.ctdb.2016 .11 .010

Guris DL, Fantes J, Tara D, Druker BJ, Imamoto A. 2001. Mice lacking the homologue of the human 22q11.2 gene CRKL phenocopy neurocristopathies of DiGeorge syndrome. Nat Genet 27: 293-298. doi:10.1038/85855

Guris DL, Duester G, Papaioannou VE, Imamoto A. 2006. Dose-dependent interaction of Tbx1 and Crkl and locally aberrant RA signaling in a model of del22q11 syndrome. Dev Cell 10: 81-92. doi:10.1016/j.devcel.2005.12.002

Haaning AM, Quinn ME, Ware SM. 2013. Heterotaxy-spectrum heart defects in Zic3 hypomorphic mice. Pediatr Res 74: 494-502. doi:10.1038/pr.2013.147

Habashi JP, Judge DP, Holm TM, Cohn RD, Loeys BL, Cooper TK, Myers L, Klein EC, Liu G, Calvi C, et al. 2006. Losartan, an AT1 antagonist, prevents aortic aneurysm in a mouse model of Marfan syndrome. Science 312: 117-121. doi:10.1126/science.1124287

High FA, Jain R, Stoller JZ, Antonucci NB, Lu MM, Loomes KM, Kaestner KH, Pear WS, Epstein JA. 2009. Murine Jagged1/Notch signaling in the second heart field orchestrates Fgf8 expression and tissue-tissue interactions during outflow tract development. J Clin Invest 119: 19861996.

Hirayama-Yamada K, Kamisago M, Akimoto K, Aotsuka H, Nakamura $Y$, Tomita H, Furutani $M$, Imamura $S$, Takao A, Nakazawa M, et al. 2005. Phenotypes with GATA4 or NKX2.5 mutations in familial atrial septal defect. Am J Med Genet A 135A: 47-52. doi:10.1002/ajmg.a.30684

Hoffmann AD, Peterson MA, Friedland-Little JM, Anderson SA, Moskowitz IP. 2009. sonic hedgehog is required in pulmonary endoderm for atrial septation. Development 136: 1761-1770. doi:10.1242/dev.034157

Homma S, Messé SR, Rundek T, Sun YP, Franke J, Davidson K, Sievert H, Sacco RL, Di Tullio MR. 2016. Patent foramen ovale. Nat Rev Dis Primers 2: 15086. doi:10.1038/ nrdp.2015.86

Howe K, Clark MD, Torroja CF, Torrance J, Berthelot C, Muffato M, Collins JE, Humphray S, McLaren K, Matthews L, et al. 2013. The zebrafish reference genome sequence and its relationship to the human genome. Nature 496: 498-503. doi:10.1038/nature12111

Hrstka SC, Li X, Nelson TJ; Wanek Program Genetics Pipeline Group. 2017. NOTCH1-dependent nitric oxide signaling deficiency in hypoplastic left heart syndrome revealed through patient-specific phenotypes detected in bioengineered cardiogenesis. Stem Cells 35: 1106-1119. doi:10.1002/stem.2582

$\mathrm{Hu}$ T, Yamagishi H, Maeda J, McAnally J, Yamagishi C, Srivastava D. 2004. Tbx1 regulates fibroblast growth factors in the anterior heart field through a reinforcing autoregulatory loop involving forkhead transcription factors. Development 131: 5491-5502. doi:10.1242/dev .01399

Jiang JQ, Li RG, Wang J, Liu XY, Xu YJ, Fang WY, Chen XZ, Zhang W, Wang XZ, Yang YQ. 2013. Prevalence and spectrum of GATA5 mutations associated with congeni- 
U. Majumdar et al.

tal heart disease. Int J Cardiol 165: 570-573. doi:10.1016/j .ijcard.2012.09.039

Jiang Y, Habibollah S, Tilgner K, Collin J, Barta T, Al-Aama JY, Tesarov L, Hussain R, Trafford AW, Kirkwood G, et al. 2014. An induced pluripotent stem cell model of hypoplastic left heart syndrome (HLHS) reveals multiple expression and functional differences in HLHS-derived cardiac myocytes. Stem Cells Transl Med 3: 416-423. doi:10 $.5966 /$ sctm.2013-0105

Jin SC, Homsy J, Zaidi S, Lu Q, Morton S, DePalma SR, Zeng X, Qi H, Chang W, Sierant MC, et al. 2017. Contribution of rare inherited and de novo variants in 2,871 congenital heart disease probands. Nat Genet 49: 1593-1601. doi:10 $.1038 /$ ng. 3970

Kassab K, Hariri H, Gharibeh L, Fahed AC, Zein M, El-Rassy I, Nemer M, El-Rassi I, Bitar F, Nemer G. 2016. GATA5 mutation homozygosity linked to a double outlet right ventricle phenotype in a Lebanese patient. Mol Genet Genomic Med 4: 160-171. doi:10.1002/mgg3.190

Kawauchi S, Calof AL, Santos R, Lopez-Burks ME, Young CM, Hoang MP, Chua A, Lao T, Lechner MS, Daniel JA, et al. 2009. Multiple organ system defects and transcriptional dysregulation in the $\mathrm{Nipbl}^{+/-}$mouse, a model of Cornelia de Lange syndrome. PLoS Genet 5: e1000650. doi:10.1371/journal.pgen.1000650

Kerstjens-Frederikse WS, van de Laar IM, Vos YJ, Verhagen JM, Berger RM, Lichtenbelt KD, Klein Wassink-Ruiter JS, van der Zwaag PA, du Marchie Sarvaas GJ, Bergman KA, et al. 2016. Cardiovascular malformations caused by NOTCH1 mutations do not keep left: data on 428 probands with left-sided CHD and their families. Genet Med 18: 914-923. doi:10.1038/gim.2015.193

Kinnear C, Chang WY, Khattak S, Hinek A, Thompson T, de Carvalho Rodrigues D, Kennedy K, Mahmut N, Pasceri P, Stanford WL, et al. 2013. Modeling and rescue of the vascular phenotype of Williams-Beuren syndrome in patient induced pluripotent stem cells. Stem Cells Transl Med 2: 2-15. doi:10.5966/sctm.2012-0054

Kodo K, Nishizawa T, Furutani M, Arai S, Yamamura E, Joo K, Takahashi T, Matsuoka R, Yamagishi H. 2009. GATA6 mutations cause human cardiac outflow tract defects by disrupting semaphorin-plexin signaling. Proc Natl Acad Sci 106: 13933-13938. doi:10.1073/pnas.0904744106

Koenig SN, Bosse K, Majumdar U, Bonachea EM, Radtke F, Garg V. 2016. Endothelial Notch1 is required for proper development of the semilunar valves and cardiac outflow tract. J Am Heart Assoc 5: e003075. doi:10.1161/JAHA .115 .003075

Koenig SN, LaHaye S, Feller JD, Rowland P, Hor KN, Trask AJ, Janssen PM, Radtke F, Lilly B, Garg V. 2017. Notch1 haploinsufficiency causes ascending aortic aneurysms in mice. JCI Insight 2: e91353. doi:10.1172/jci.insight.91353

Laforest B, Nemer M. 2011. GATA5 interacts with GATA4 and GATA6 in outflow tract development. Dev Biol 358: 368-378. doi:10.1016/j.ydbio.2011.07.037

Laforest B, Andelfinger G, Nemer M. 2011. Loss of Gata5 in mice leads to bicuspid aortic valve. J Clin Invest 121: 2876-2887. doi:10.1172/JCI44555

LaHaye S, Majumdar U, Yasuhara J, Koenig SN, MatosNieves A, Kumar R, Garg V. 2019. Developmental origins for semilunar valve stenosis identified in mice harboring congenital heart disease-associated GATA4 mutation. Dis Model Mech 12: dmm036764. doi:10.1242/dmm.036764

Lana-Elola E, Watson-Scales S, Slender A, Gibbins D, Martineau A, Douglas C, Mohun T, Fisher EM, Tybulewicz V. 2016. Genetic dissection of Down syndrome-associated congenital heart defects using a new mouse mapping panel. eLife 5: e11614. doi:10.7554/eLife.11614

Lania G, Bresciani A, Bisbocci M, Francone A, Colonna V, Altamura S, Baldini A. 2016. Vitamin B12 ameliorates the phenotype of a mouse model of DiGeorge syndrome. Hum Mol Genet 25: 4369-4375.

Li QY, Newbury-Ecob RA, Terrett JA, Wilson DI, Curtis AR, Yi CH, Gebuhr T, Bullen PJ, Robson SC, Strachan T, et al. 1997. Holt-Oram syndrome is caused by mutations in TBX5, a member of the Brachyury (T) gene family. Nat Genet 15: 21-29. doi:10.1038/ng0197-21

Li DY, Faury G, Taylor DG, Davis EC, Boyle WA, Mecham RP, Stenzel P, Boak B, Keating MT. 1998. Novel arterial pathology in mice and humans hemizygous for elastin. Clin Invest 102: 1783-1787. doi:10.1172/JCI4487

Lindsay EA. 2001. Chromosomal microdeletions: dissecting del22q11 syndrome. Nat Rev Genet 2: 858-868. doi:10 $.1038 / 35098574$

Lindsay EA, Botta A, Jurecic V, Carattini-Rivera S, Cheah YC, Rosenblatt HM, Bradley A, Baldini A. 1999. Congenital heart disease in mice deficient for the DiGeorge syndrome region. Nature 401: 379-383.

Lindsay EA, Vitelli F, Su H, Morishima M, Huynh T, Pramparo T, Jurecic V, Oguninu G, Sutherland HF, Scambler PJ, et al. 2001. Tbx1 haploinsufficieny in the DiGeorge syndrome region causes aortic arch defects in mice. $\mathrm{Na}$ ture 410: 97-101. doi:10.1038/35065105

Liu X, Yagi H, Saeed S, Bais AS, Gabriel GC, Chen Z, Peterson KA, Li Y, Schwartz MC, Reynolds WT, et al. 2017. The complex genetics of hypoplastic left heart syndrome. Nat Genet 49: 1152-1159. doi:10.1038/ng.3870

MacGrogan D, D'Amato G, Travisano S, Martinez-Poveda B, Luxán G, Del Monte-Nieto G, Papoutsi T, Sbroggio M Bou V, Gomez-Del Arco P, et al. 2016. Sequential liganddependent Notch signaling activation regulates valve primordium formation and morphogenesis. Circ Res 118: 1480-1497. doi:10.1161/CIRCRESAHA.115.308077

Maeda J, Yamagishi H, McAnally J, Yamagishi C, Srivastava D. 2006. Tbx1 is regulated by forkhead proteins in the secondary heart field. Dev Dyn 235: 701-710. doi:10 $.1002 /$ dvdy.20686

Mahadevia R, Barker AJ, Schnell S, Entezari P, Kansal P, Fedak PW, Malaisrie SC, McCarthy P, Collins J, Carr J, et al. 2014. Bicuspid aortic cusp fusion morphology alters aortic three-dimensional outflow patterns, wall shear stress, and expression of aortopathy. Circulation 129: 673-682. doi:10.1161/CIRCULATIONAHA.113.003026

Maitra M, Koenig SN, Srivastava D, Garg V. 2010. Identification of GATA6 sequence variants in patients with congenital heart defects. Pediatr Res 68: 281-285. doi:10 .1203/PDR.0b013e3181ed17e4

McBride KL, Pignatelli R, Lewin M, Ho T, Fernbach S, Menesses A, Lam W, Leal SM, Kaplan N, Schliekelman P, et al. 2005. Inheritance analysis of congenital left ventricular outflow tract obstruction malformations: segregation, multiplex relative risk, and heritability. Am J Med Genet A 134A: 180-186. doi:10.1002/ajmg.a.30602 
McBride KL, Riley MF, Zender GA, Fitzgerald-Butt SM, Towbin JA, Belmont JW, Cole SE. 2008. NOTCH1 mutations in individuals with left ventricular outflow tract malformations reduce ligand-induced signaling. Hum Mol Genet 17: 2886-2893. doi:10.1093/hmg/ddn187

McFadden DG, Barbosa AC, Richardson JA, Schneider MD, Srivastava D, Olson EN. 2005. The Hand1 and Hand2 transcription factors regulate expansion of the embryonic cardiac ventricles in a gene dosage-dependent manner. Development 132: 189-201. doi:10.1242/dev.01562

Mercer EJ, Evans T. 2017. Congenital heart disease in a dish: progress toward understanding patient-specific mutations. J Thorac Dis 9: E510-E513. doi:10.21037/jtd.2017 .03 .178

Merscher S, Funke B, Epstein JA, Heyer J, Puech A, Lu MM, Xavier RJ, Demay MB, Russell RG, Factor S, et al. 2001. TBX1 is responsible for cardiovascular defects in velocardio-facial/DiGeorge syndrome. Cell 104: 619-629. doi:10.1016/S0092-8674(01)00247-1

Misra C, Sachan N, McNally CR, Koenig SN, Nichols HA, Guggilam A, Lucchesi PA, Pu WT, Srivastava D, Garg V. 2012. Congenital heart disease-causing Gata4 mutation displays functional deficits in vivo. PLoS Genet 8: e1002690. doi:10.1371/journal.pgen.1002690

Mital S. 2016. Human pluripotent stem cells to model congenital heart disease. In Etiology and morphogenesis of congenital heart disease: from gene function and cellular interaction to morphology (ed. Nakanishi T, et al.), pp. 321-327. Springer, Tokyo.

Momma K. 2010. Cardiovascular anomalies associated with chromosome 22q11.2 deletion syndrome. Am J Cardiol 105: 1617-1624. doi:10.1016/j.amjcard.2010.01.333

Moon AM, Guris DL, Seo JH, Li L, Hammond J, Talbot A, Imamoto A. 2006. Crkl deficiency disrupts Fgf8 signaling in a mouse model of 22q11 deletion syndromes. Dev Cell 10: 71-80. doi:10.1016/j.devcel.2005.12.003

Musunuru K, Sheikh F, Gupta RM, Houser SR, Maher KO, Milan DJ, Terzic A, Wu JC; American Heart Association Council on Functional Genomics and Translational Biology; Council on Cardiovascular Disease in the Young, et al. 2018. Induced pluripotent stem cells for cardiovascular disease modeling and precision medicine: a scientific statement from the American Heart Association. Circ Genom Precis Med 11: e000043.

Nadeau M, Georges RO, Laforest B, Yamak A, Lefebvre C, Beauregard J, Paradis P, Bruneau BG, Andelfinger G, Nemer M. 2010. An endocardial pathway involving Tbx5, Gata4, and Nos3 required for atrial septum formation. Proc Natl Acad Sci 107: 19356-19361. doi:10.1073/ pnas. 0914888107

Nemer G, Fadlalah F, Usta J, Nemer M, Dbaibo G, Obeid M, Bitar F. 2006. A novel mutation in the GATA4 gene in patients with tetralogy of Fallot. Hum Mutat 27: 293-294. doi:10.1002/humu.9410

Newbury-Ecob RA, Leanage R, Raeburn JA, Young ID. 1996. Holt-Oram syndrome: a clinical genetic study. J Med Genet 33: 300-307. doi:10.1136/jmg.33.4.300

Ng CM, Cheng A, Myers LA, Martinez-Murillo F, Jie C, Bedja D, Gabrielson KL, Hausladen JM, Mecham RP, Judge DP, et al. 2004. TGF- $\beta$-dependent pathogenesis of mitral valve prolapse in a mouse model of Marfan syn- drome. J Clin Invest 114: 1586-1592. doi:10.1172/JCI 200422715

Nigam V, Srivastava D. 2009. Notch1 represses osteogenic pathways in aortic valve cells. J Mol Cell Cardiol 47: 828834. doi:10.1016/j.yjmcc.2009.08.008

Nus M, MacGrogan D, Martínez-Poveda B, Benito Y, Casanova JC, Fernández-Avilés F, Bermejo J, de la Pompa JL. 2011. Diet-induced aortic valve disease in mice haploinsufficient for the Notch pathway effector RBPJK/CSL. Arterioscler Thromb Vasc Biol 31: 1580-1588. doi:10 .1161/ATVBAHA.111.227561

O’Doherty A, Ruf S, Mulligan C, Hildreth V, Errington ML, Cooke S, Sesay A, Modino S, Vanes L, Hernandez D, et al. 2005. An aneuploid mouse strain carrying human chromosome 21 with Down syndrome phenotypes. Science 309: 2033-2037. doi:10.1126/science.1114535

Oike Y, Hata A, Mamiya T, Kaname T, Noda Y, Suzuki M, Yasue H, Nabeshima T, Araki K, Yamamura K. 1999. Truncated CBP protein leads to classical RubinsteinTaybi syndrome phenotypes in mice: implications for a dominant-negative mechanism. Hum Mol Genet 8: 387396. doi:10.1093/hmg/8.3.387

Okubo A, Miyoshi O, Baba K, Takagi M, Tsukamoto K, Kinoshita A, Yoshiura K, Kishino T, Ohta T, Niikawa $\mathrm{N}$, et al. 2004. A novel GATA4 mutation completely segregated with atrial septal defect in a large Japanese family. J Med Genet 41: e97. doi:10.1136/jmg.2004.018895

Padang R, Bagnall RD, Richmond DR, Bannon PG, Semsarian C. 2012. Rare non-synonymous variations in the transcriptional activation domains of GATA5 in bicuspid aortic valve disease. J Mol Cell Cardiol 53: 277-281. doi:10 $.1016 /$ j.yjmcc.2012.05.009

Page DJ, Miossec MJ, Williams SG, Monaghan RM, Fotiou E, Cordell HJ, Sutcliffe L, Topf A, Bourgey M, Bourque G, et al. 2019. Whole exome sequencing reveals the major genetic contributors to nonsyndromic tetralogy of Fallot. Circ Res 124: 553-563. doi:10.1161/CIRCRESAHA.118 .313250

Pierpont ME, Brueckner M, Chung WK, Garg V, Lacro RV, McGuire AL, Mital S, Priest JR, Pu WT, Roberts A, et al. 2018. Genetic basis for congenital heart disease: revisited: a scientific statement from the American Heart Association. Circulation 138: e653-e711. doi:10.1161/CIR.000 0000000000606

Pizzuti A, Sarkozy A, Newton AL, Conti E, Flex E, Digilio MC, Amati F, Gianni D, Tandoi C, Marino B, et al. 2003. Mutations of ZFPM2/FOG2 gene in sporadic cases of tetralogy of Fallot. Hum Mutat 22: 372-377. doi:10 $.1002 /$ humu. 10261

Purandare SM, Ware SM, Kwan KM, Gebbia M, Bassi MT, Deng JM, Vogel H, Behringer RR, Belmont JW, Casey B. 2002. A complex syndrome of left-right axis, central nervous system and axial skeleton defects in Zic3 mutant mice. Development 129: 2293-2302.

Quintero-Rivera F, Xi QJ, Keppler-Noreuil KM, Lee JH, Higgins AW, Anchan RM, Roberts AE, Seong IS, Fan X, Lage $\mathrm{K}$, et al. 2015. MATR3 disruption in human and mouse associated with bicuspid aortic valve, aortic coarctation and patent ductus arteriosus. Hum Mol Genet 24: 23752389. doi:10.1093/hmg/ddv004

Racedo SE, Hasten E, Lin M, Devakanmalai GS, Guo T, Ozbudak EM, Cai CL, Zheng D, Morrow BE. 2017. Re- 
U. Majumdar et al.

duced dosage of $\beta$-catenin provides significant rescue of cardiac outflow tract anomalies in a Tbx1 conditional null mouse model of 22q11.2 deletion syndrome. PLoS Genet 13: e1006687. doi:10.1371/journal.pgen.1006687

Rajagopal SK, Ma Q, Obler D, Shen J, Manichaikul A, Tomita-Mitchell A, Boardman K, Briggs C, Garg V, Srivastava D, et al. 2007. Spectrum of heart disease associated with murine and human GATA4 mutation. $J$ Mol Cell Cardiol 43: 677-685. doi:10.1016/j.yjmcc.2007.06.004

Randall V, McCue K, Roberts C, Kyriakopoulou V, Beddow S, Barrett AN, Vitelli F, Prescott K, Shaw-Smith C, Devriendt $\mathrm{K}$, et al. 2009. Great vessel development requires biallelic expression of Chd7 and Tbxl in pharyngeal ectoderm in mice. J Clin Invest 119: 3301-3310.

Reiter LT, Potocki L, Chien S, Gribskov M, Bier E. 2001. A systematic analysis of human disease-associated gene sequences in Drosophila melanogaster. Genome Res 11: 1114-1125. doi:10.1101/gr.169101

Roessler E, Ouspenskaia MV, Karkera JD, Vélez JI, Kantipong A, Lacbawan F, Bowers P, Belmont JW, Towbin JA, Goldmuntz E, et al. 2008. Reduced NODAL signaling strength via mutation of several pathway members including FOXH1 is linked to human heart defects and holoprosencephaly. Am J Hum Genet 83: 18-29. doi:10 .1016/j.ajhg.2008.05.012

Russell MW, Chung WK, Kaltman JR, Miller TA. 2018. Advances in the understanding of the genetic determinants of congenital heart disease and their impact on clinical outcomes. J Am Heart Assoc 7: e006906. doi:10.1161/ JAHA.117.006906

Ryu J, Prather RS, Lee K. 2018. Use of gene-editing technology to introduce targeted modifications in pigs. J Anim Sci Biotechnol 9: 5. doi:10.1186/s40104-017-0228-7

Sarkozy A, Conti E, Neri C, D’Agostino R, Digilio MC, Esposito G, Toscano A, Marino B, Pizzuti A, Dallapiccola B. 2005. Spectrum of atrial septal defects associated with mutations of NKX2.5 and GATA4 transcription factors. J Med Genet 42: e16. doi:10.1136/jmg.2004.026740

Schluterman MK, Krysiak AE, Kathiriya IS, Abate N, Chandalia M, Srivastava D, Garg V. 2007. Screening and biochemical analysis of GATA4 sequence variations identified in patients with congenital heart disease. Am J Med Genet A 143A: 817-823. doi:10.1002/ajmg.a.31652

Schott JJ, Benson DW, Basson CT, Pease W, Silberbach GM, Moak JP, Maron BJ, Seidman CE, Seidman JG. 1998. Congenital heart disease caused by mutations in the transcription factor NKX2-5. Science 281: 108-111. doi:10 $.1126 /$ science.281.5373.108

Schulkey CE, Regmi SD, Magnan RA, Danzo MT, Luther H, Hutchinson AK, Panzer AA, Grady MM, Wilson DB, Jay PY. 2015. The maternal-age-associated risk of congenital heart disease is modifiable. Nature 520: 230-233. doi:10 $.1038 /$ nature 14361

Shi LM, Tao JW, Qiu XB, Wang J, Yuan F, Xu L, Liu H, Li RG, Xu YJ, Wang Q, et al. 2014. GATA5 loss-of-function mutations associated with congenital bicuspid aortic valve. Int J Mol Med 33: 1219-1226. doi:10.3892/ijmm.2014 .1700

Shikama N, Lutz W, Kretzschmar R, Sauter N, Roth JF, Marino S, Wittwer J, Scheidweiler A, Eckner R. 2003. Essential function of p300 acetyltransferase activity in heart, lung and small intestine formation. $Е M B O J$ 22: 5175-5185. doi:10.1093/emboj/cdg502

Sifrim A, Hitz M-P, Wilsdon A, Breckpot J, Turki SHA, Thienpont B, McRae J, Fitzgerald TW, Singh T, Swaminathan GJ, et al. 2016. Distinct genetic architectures for syndromic and nonsyndromic congenital heart defects identified by exome sequencing. Nat Genet 48: 10601065. doi:10.1038/ng.3627

Stallmeyer B, Fenge H, Nowak-Göttl U, Schulze-Bahr E. 2010. Mutational spectrum in the cardiac transcription factor gene NKX2.5 (CSX) associated with congenital heart disease. Clin Genet 78: 533-540. doi:10.1111/j .1399-0004.2010.01422.x

Tevosian SG, Deconinck AE, Tanaka M, Schinke M, Litovsky SH, Izumo S, Fujiwara Y, Orkin SH. 2000. FOG-2, a cofactor for GATA transcription factors, is essential for heart morphogenesis and development of coronary vessels from epicardium. Cell 101: 729-739. doi:10.1016/ S0092-8674(00)80885-5

Theodoris CV, Li M, White MP, Liu L, He D, Pollard KS, Bruneau BG, Srivastava D. 2015. Human disease modeling reveals integrated transcriptional and epigenetic mechanisms of NOTCH1 haploinsufficiency. Cell 160: 1072-1086. doi:10.1016/j.cell.2015.02.035

Theodoris CV, Mourkioti F, Huang Y, Ranade SS, Liu L, Blau HM, Srivastava D. 2017. Long telomeres protect against age-dependent cardiac disease caused by NOTCH1 haploinsufficiency. JClin Invest 127: 1683-1688. doi:10.1172/ JCI90338

Töpf A, Griffin HR, Glen E, Soemedi R, Brown DL, Hall D, Rahman TJ, Eloranta JJ, Jüngst C, Stuart AG, et al. 2014. Functionally significant, rare transcription factor variants in tetralogy of Fallot. PLoS One 9: e95453. doi:10.1371/ journal.pone.0095453

Verma S, Siu SC. 2014. Aortic dilatation in patients with bicuspid aortic valve. $N$ Engl J Med 370: 1920-1929. doi:10.1056/NEJMra1207059

Vogler G, Bodmer R. 2015. Cellular mechanisms of Drosophila heart morphogenesis. J Cardiovasc Dev Dis 2: 2-16. doi:10.3390/jcdd2010002

Wang J, Sridurongrit S, Dudas M, Thomas P, Nagy A, Schneider MD, Epstein JA, Kaartinen V. 2005. Atrioventricular cushion transformation is mediated by ALK2 in the developing mouse heart. Dev Biol 286: 299-310. doi:10.1016/j.ydbio.2005.07.035

Wang Y, Wu B, Farrar E, Lui W, Lu P, Zhang D, Alfieri CM, Mao K, Chu M, Yang D, et al. 2017. Notch-Tnf signalling is required for development and homeostasis of arterial valves. Eur Heart J 38: 675-686.

Wei D, Bao H, Liu XY, Zhou N, Wang Q, Li RG, Xu YJ, Yang YQ. 2013. GATA5 loss-of-function mutations underlie tetralogy of Fallot. Int J Med Sci 10: 34-42. doi:10.7150/ ijms.5270

Winnier GE, Kume T, Deng K, Rogers R, Bundy J, Raines C, Walter MA, Hogan BL, Conway SJ. 1999. Roles for the winged helix transcription factors MF1 and MFH1 in cardiovascular development revealed by nonallelic noncomplementation of null alleles. Dev Biol 213: 418-431. doi:10.1006/dbio.1999.9382

Winston JB, Erlich JM, Green CA, Aluko A, Kaiser KA, Takematsu M, Barlow RS, Sureka AO, LaPage MJ, Janss LL, et al. 2010. Heterogeneity of genetic modifiers ensures 
normal cardiac development. Circulation 121: 13131321. doi:10.1161/CIRCULATIONAHA.109.887687

Yamagishi H, Srivastava D. 2003. Unraveling the genetic and developmental mysteries of 22q11 deletion syndrome. Trends Mol Med 9: 383-389. doi:10.1016/S1471-4914 (03)00141-2

Yamamoto M, Meno C, Sakai Y, Shiratori H, Mochida K, Ikawa Y, Saijoh Y, Hamada H. 2001. The transcription factor FoxH1 (FAST) mediates Nodal signaling during anterior-posterior patterning and node formation in the mouse. Genes Dev 15: 1242-1256. doi:10.1101/gad .883901

Yamamoto M, Mine N, Mochida K, Sakai Y, Saijoh Y, Meno C, Hamada H. 2003. Nodal signaling induces the midline barrier by activating Nodal expression in the lateral plate. Development 130: 1795-1804. doi:10.1242/dev.00408

Yang C, Xu Y, Yu M, Lee D, Alharti S, Hellen N, Ahmad Shaik N, Banaganapalli B, Sheikh Ali Mohamoud H, Elango R, et al. 2017. Induced pluripotent stem cell modelling of HLHS underlines the contribution of dysfunctional NOTCH signalling to impaired cardiogenesis. Hum Mol Genet 26: 3031-3045. doi:10.1093/hmg/ddx140

Yi J, Chen M, Wu X, Yang X, Xu T, Zhuang Y, Han M, Xu R. 2010. Endothelial SUR-8 acts in an ERK-independent pathway during atrioventricular cushion development. Dev Dyn 239: 2005-2013. doi:10.1002/dvdy.22343

Yu T, Li Z, Jia Z, Clapcote SJ, Liu C, Li S, Asrar S, Pao A, Chen R, Fan N, et al. 2010. A mouse model of Down syndrome
Genetic Models of Congenital Heart Disease

trisomic for all human chromosome 21 syntenic regions. Hum Mol Genet 19: 2780-2791. doi:10.1093/hmg/ddq 179

Zakariyah AF, Rajgara RF, Veinot JP, Skerjanc IS, Burgon PG. 2017. Congenital heart defect causing mutation in $\mathrm{Nkx} 2.5$ displays in vivo functional deficit. J Mol Cell Cardiol 105: 89-98. doi:10.1016/j.yjmcc.2017.03.003

Zhang Z, Baldini A. 2008. In vivo response to high-resolution variation of Tbx1 mRNA dosage. Hum Mol Genet 17: 150-157. doi:10.1093/hmg/ddm291

Zhang Z, Cerrato F, Xu H, Vitelli F, Morishima M, Vincentz J, Furuta Y, Ma L, Martin JF, Baldini A, et al. 2005. Tbxl expression in pharyngeal epithelia is necessary for pharyngeal arch artery development. Development 132: 5307-5315. doi:10.1242/dev.02086

Zhou L, Liu J, Xiang M, Olson P, Guzzetta A, Zhang K, Moskowitz IP, Xie L. 2017. Gata4 potentiates second heart field proliferation and Hedgehog signaling for cardiac septation. Proc Natl Acad Sci 114: E1422-E1431. doi:10 $.1073 /$ pnas.1605137114

Zhu JY, Fu Y, Nettleton M, Richman A, Han Z. 2017a. High throughput in vivo functional validation of candidate congenital heart disease genes in Drosophila. eLife 6: e22617. doi:10.7554/eLife.22617

Zhu JY, Fu Y, Richman A, Han Z. 2017b. Validating candidate congenital heart disease genes in Drosophila. Bio Protoc 7: e2350. doi:10.21769/BioProtoc.2350 


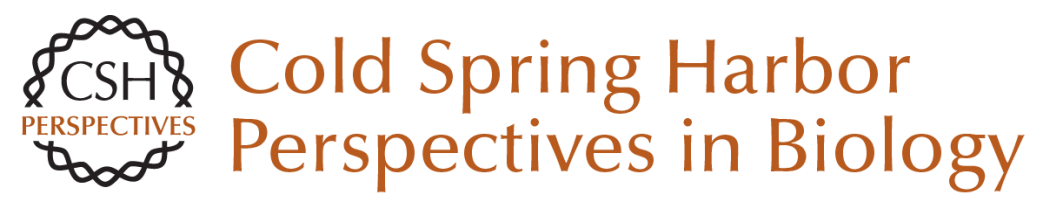

\section{In Vivo and In Vitro Genetic Models of Congenital Heart Disease}

Uddalak Majumdar, Jun Yasuhara and Vidu Garg

Cold Spring Harb Perspect Biol 2021; doi: 10.1101/cshperspect.a036764 originally published online December 9, 2019

\section{Subject Collection Heart Development and Disease}

Epicardium in Heart Development

Yingxi Cao, Sierra Duca and Jingli Cao

Cardiac Neural Crest

Hiroyuki Yamagishi

The Endocardium and Heart Valves Bailey Dye and Joy Lincoln

Long Noncoding RNAs in Cardiac Development Michael Alexanian and Samir Ounzain

Genetic Basis of Human Congenital Heart Disease Shannon N. Nees and Wendy K. Chung

Cardiopharyngeal Progenitor Specification:

Multiple Roads to the Heart and Head Muscles Benjamin Swedlund and Fabienne Lescroart

Genetic and Epigenetic Control of Heart Development

Brynn N. Akerberg and William T. Pu

Formation and Growth of Cardiac Lymphatics during Embryonic Development, Heart Regeneration, and Disease

Dana Gancz, Gal Perlmoter and Karina Yaniv
In Vivo and In Vitro Genetic Models of Congenital Heart Disease

Uddalak Majumdar, Jun Yasuhara and Vidu Garg

Development of the Cardiac Conduction System

Samadrita Bhattacharyya and Nikhil V. Munshi

3D Anatomy of the Developing Heart:

Understanding Ventricular Septation

Timothy J. Mohun and Robert H. Anderson

Cardiac Morphogenesis: Specification of the

Four-Chambered Heart

Vincent Christoffels and Bjarke Jensen

The Chicken as a Model Organism to Study Heart

Development

Johannes G. Wittig and Andrea Münsterberg

The First Heartbeat--Origin of Cardiac Contractile

Activity

Richard C.V. Tyser and Shankar Srinivas

Xenopus: Experimental Access to Cardiovascular

Development, Regeneration Discovery, and

Cardiovascular Heart-Defect Modeling Stefan Hoppler and Frank L. Conlon

Reptiles as a Model System to Study Heart

Development

Bjarke Jensen and Vincent M. Christoffels

For additional articles in this collection, see http://cshperspectives.cshlp.org/cgi/collection/

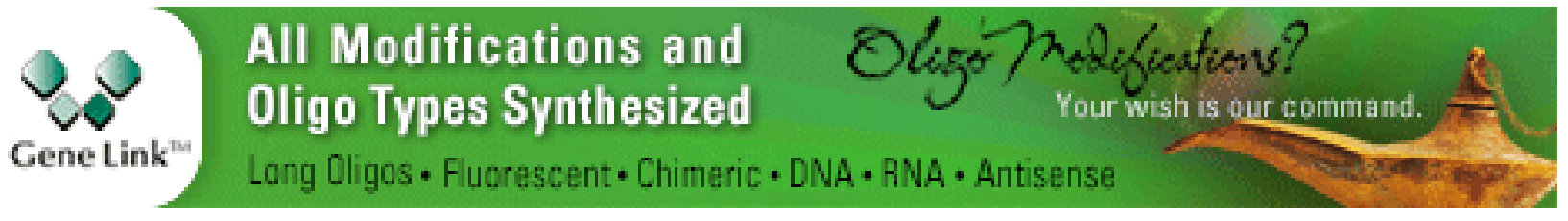

Copyright @ 2021 Cold Spring Harbor Laboratory Press; all rights reserved 